4

5

$8 *$ Corresponding author.

9 E-mail addresses: jpstone@vims.edu (J. Stone), debbies@vims.edu (D. Steinberg)

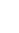

Joshua P. Stone ${ }^{\mathrm{a}, *}$, Deborah K. Steinberg ${ }^{\mathrm{a}}$

${ }^{a}$ Department of Biological Sciences, Virginia Institute of Marine Science, College of William \& Mary, PO Box 1346, Gloucester Point, VA 23062, USA

\title{
Salp contributions to vertical carbon flux in the Sargasso Sea
} 10 1 
Abstract

We developed a one-dimensional model to estimate salp contributions to vertical carbon flux at the Bermuda Atlantic Time-series Study (BATS) site in the North Atlantic subtropical gyre for a 17-yr period (April 1994 to December 2011). We based the model parameters on published rates of salp physiology and experimentally determined sinking and decomposition rates of salp carcasses. Salp grazing was low during non-bloom conditions, but routinely exceeded $100 \%$ of chlorophyll standing stock and primary production during blooms. Fecal pellet production was the largest source of salp carbon flux (78\% of total), followed by respiration below 200m (19\%), sinking of carcasses (3\%), and DOC excretion below 200m (<0.1\%). Thalia democratica, Salpa fusiformis, Salpa aspera, Wheelia cylindrica, and Iasis zonaria were the five highest contributors, accounting for $95 \%$ of total salp-mediated carbon flux. Seasonally, salp flux was higher during spring-summer than fall-winter, due to seasonal changes in species composition and abundance. Salp carbon export to $200 \mathrm{~m}$ was on average $2.3 \mathrm{mg} \mathrm{C} \mathrm{m}^{-2} \mathrm{~d}^{-1}$ across the entire time series. This is equivalent to $11 \%$ of the mean $200 \mathrm{~m}$ POC flux measured by sediment traps in the region. Salp blooms were particularly productive, accounting for $79 \%$ of the total modeled salp POC flux at 200m across the time series. Salp carbon flux attenuated slowly, and at 3200m the average modeled carbon from salps was $109 \%$ of the POC flux measured in sediment traps at that depth. Migratory and carcass carbon export pathways should also be considered (alongside fecal pellet flux) as facilitating carbon export to sequestration depths in future studies.

Keywords: Salps, Thaliacea, Carbon export, Sargasso Sea, Biological Pump, fecal pellet 
Introduction

The Sargasso Sea is an oligotrophic region in the North Atlantic subtropical gyre, with patterns in biogeochemistry influenced by physical forcing, moderated by strength of winter mixing, and tied to decadal-scale climate oscillations (Saba et al. 2010, Álvarez-García et al. 2011, Wu et al. 2011). In years with increased frequency of winter mixing, increased surface nutrients fuel new production, ultimately leading to higher particulate organic carbon fluxes to $150 \mathrm{~m}$ (Lomas et al. 2010). As this mass flux continues to sink, organic carbon content decreases from $11.4 \%$ of the total at $500 \mathrm{~m}$ to only $4.6 \%$ at 3200m, indicating high remineralization by bacteria and deep-sea zooplankton (Conte et al. 2001), although physical fragmentation of larger particles into smaller, non-sinking particles may also occur. In the Sargasso Sea, flux to the meso- and bathypelagic zones consists of phytodetritus, amorphous aggregates, zooplankton fecal pellets, and foraminifera shells (Shatova et al. 2012, Conte \& Weber 2014), with variation in mass flux closely coupled to seasonal changes in epipelagic particle flux (Conte et al. 2001, Lomas et al. 2010). Flux is also influenced by climate oscillations, with higher nitrogen flux to 3200m in years with a negative North Atlantic Oscillation (NAO) anomaly (Conte \& Weber 2014). Interannual variations in mesozooplankton biomass in this region also affect vertical export (Steinberg et al. 2012); we examine here how fluctuations in salp populations (Stone and Steinberg 2014) contribute to vertical carbon flux through a variety of mechanisms.

Salps are gelatinous, tubular zooplankton which alternate life stages between solitary, sexuallyproduced individuals and aggregated, asexually-produced colonies-ranging in size from a few mm's to tens of m's in length. Salps are highly efficient filter feeders, with clearance rates up to several liters salp ${ }^{1}$ hour $^{-1}$ (Madin and Cetta 1984, Andersen 1985, Vargas and Madin 2004), and they can consume a broad size range of phytoplankton and bacteria (Bone et al. 2003, Sutherland et al. 2010). Salps feed incessantly as they propel themselves through the water, and when numerous, can consume up to $3.5 \%$ of the chlorophyll standing stock (Hereu et al. 2006). Their continuous ingestion of a wide range of particle sizes promotes rapid rates of growth, reproduction, and defecation. Salp fecal pellets are relatively large 
62

63

64

65

66

67

68

69

70

71

72

73

74

75

76

77

78

79

80

81

82

83

84

85

86

(Caron et al. 1989, Sutherland et al. 2010), and sink at rates up to $1600 \mathrm{~m} \mathrm{day}^{-1}$ (Bruland and Silver 1981, Phillips et al. 2009). Due to fast sinking velocities, salp pellets can reach bathypelagic depths relatively intact, and are found in high numbers in sediment traps (Iseki 1981, Matsueda et al. 1986, Caron et al. 1989, Conte et al. 2001). This observation suggests remineralization or scavenging of these particles by microbes or other metazoans may be limited.

Dead carcasses of salps also contribute to vertical export of organic matter (Lebrato et al. 2013a). While the fate of many salp blooms is unknown, seasonal blooms of salps often quickly collapse (Purcell et al. 2001), and this sudden production of carcasses can represent an important source of food for deepsea animals and bacteria (Cacchione et al. 1978, Wiebe et al. 1979, Lebrato et al. 2012). Flux from salp fecal pellets and carcasses are estimated to contribute up to $72 \%$ of the measured flux in the coastal Mediterranean (Andersen and Nival 1988), and a Salpa sp. bloom in the northeastern Pacific resulted in a major deposition of fecal pellets and carcasses to the seafloor (Smith et al. 2014). In addition to producing fecal pellets and carcasses, several abundant species of salps in the Sargasso Sea and elsewhere undergo diel vertical migration, spending time well below the pycnocline during the day and migrating to surface waters at night (Wiebe et al. 1979, Madin et al. 1996, Stone and Steinberg 2014). While at depth, vertical migrators metabolize particulate organic carbon (POC) consumed in surface waters, respiring it as $\mathrm{CO}_{2}$ and excreting dissolved organic carbon (DOC), contributing to vertical transport of carbon to depth (Steinberg et al. 2001).

While salps are important contributors to vertical carbon flux while they are present, their populations are quite variable. Salps periodically bloom throughout the world's oceans, including in the Sargasso Sea (Madin et al. 1996, 2001, Roman et al. 2002, Stone and Steinberg 2014), where they are occasionally the dominant epipelagic zooplankton (Stone and Steinberg 2014). Salps are sensitive to interannual and longer-term changes in the environment, mostly related to variations in temperature and stratification. Shifts in prevailing wind led to temperature and primary production changes that caused salp species composition in the Mediterranean to alternate between Thalia democratica and Salpa 
87 fusiformis (Ménard et al. 1994, Licandro et al. 2006). Increases in temperature, as measured by the

88 Northern Hemisphere Temperature anomaly, caused observed increases in the pelagic tunicate Pyrosoma

89

90

91

92

93

94

95

96

97

atlanticum due to more stable water masses and decreases in phytoplankoton community size (Lebrato et al. 2013b). Long-term regional changes in salp populations have been reported in the California Current (Lavaniegos \& Ohman 2007) where shifts in temperature regimes caused changes to both their species composition and biomass. In the Southern Ocean, changes in El Niño-Southern Oscillation (ENSO) and regional warming are correlated with increases in salps (Atkinson et al. 2004, Loeb et al. 2010), and worldwide, gelatinous zooplankton fluctuations are linked to oscillations in climate indices (Condon et al. 2013). In the Sargasso Sea, biomass of the salps Thalia democratica and Cyclosalpa polae increased over the last 20 years, and was positively correlated with water column stratification (Stone and Steinberg 2014). T. democratica abundance was also higher within cyclonic eddies in the Sargasso Sea, possibly through increased eddy-induced production or through eddy-wind aggregation (Stone and Steinberg 2014). These long-term changes in salps in the Sargasso Sea could increase carbon export to the deep sea.

In this study, we hypothesize that all three mechanisms of salp-mediated carbon export -1 ) sinking of fecal pellets, 2) sinking of carcasses, and 3) respiration and excretion at depth-represent significant pathways of export. To test this hypothesis, we used salp abundance and species composition data from the Bermuda Atlantic Time-series Study (BATS) to individually model each species' contributions to vertical carbon flux. This one-dimensional model includes previously-published rates of salp fecal pellet production and sinking, newly measured rates of salp carcass decomposition and sinking, and previously published rates of salp metabolism. By modeling each species and export mechanism separately, we can estimate total salp contributions to vertical flux in an oligotrophic, open-ocean environment and how those fluxes change through the water column as salp abundance and species composition change. 
Salps used in sinking and decomposition rate experiments were collected in the western North Atlantic subtropical gyre at stations within $\sim 100 \mathrm{~km}$ of the Bermuda Atlantic Time-series Study (BATS) sampling site $\left(31^{\circ} 40^{\prime} \mathrm{N}, 64^{\circ} 10^{\prime} \mathrm{W}\right)$. Cruises were aboard the R/V Atlantic Explorer during the 'Trophic BATS' project from July 19-31, 2012 and on regular monthly BATS cruises from March 4-7, April 28 May 3, and August 19-23, 2014. Salps were collected using a net with a $0.8 \times 1.2 \mathrm{~m}$ rectangular mouth, $202 \mu \mathrm{m}$ mesh, and a non-filtering cod end to minimize damage to the salps. Tows were conducted during both day and night to depths of 50-150m, and lasted $\sim 50$ minutes each. Immediately after each tow, captured salps were separated from other zooplankton and brought into the lab for experimentation. Any particles or other zooplankton stuck to the outside or inside of the salps were first removed. Salps were then identified to species and life stage, and individual salp length was measured as the oral-atrial distance using digital calipers. Salps that were not already dead post capture were killed by placing them in a shallow pan of seawater ( $2 \mathrm{~mm}$ deep) to collapse and suffocate them while allowing them to remain moist. of a clear acrylic tube $60 \mathrm{~cm}$ long and $15 \mathrm{~cm}$ in diameter filled with surface seawater. This experimental set up and sinking chamber is similar to those used in Lebrato et al. (2013a), which were $12.5 \mathrm{~cm}$ and $19 \mathrm{~cm}$ in diameter. The chamber diameter in relation to the size of some of the salps may allow flow interactions between the salp and the wall, slowing the salp sinking rate. To correct for this, we used equation 12 from Ristow et al. (1997) to apply a sidewall correction factor to each individual salp's 133 sinking rate based on the size of the salp. Water temperature was measured using a Cole-Parmer 134 Traceable ${ }^{8}$ 90205-22 temperature probe, and salinity was determined from the ship's flow-through 135 salinometer. Water temperature in the sinking chamber changed less than $1^{\circ} \mathrm{C}$ throughout each 
experimental run, and salps were stored in water with the same temperature and salinity as the sinking chamber. After placement in the sinking chamber using forceps, salps were gently shaken to remove any bubbles on or inside the salps. If any bubbles remained, the salp was discarded. Each salp was then gently released and allowed to sink. Depth of each salp in the sinking chamber was determined by comparison to measurement markings on the outside of the chamber. Once each salp appeared to reach terminal velocity (after $\sim 20 \mathrm{~cm}$ ), a timer was started, and the time to sink a distance between 5 and $30 \mathrm{~cm}$ was recorded. Different sinking distances were used when an individual salp sank particularly quickly or slowly, as we attempted to time each sinking salp for 30-60 seconds. Each salp was sunk once to avoid retrieving the salp from the bottom of the chamber and introducing turbulence.

Decomposition rate experiments were conducted with Cyclosalpa polae, Iasis zonaria, $S$. fusiformis, S. maxima, Thalia democratica, Wheelia cylindrica, and Ritteriella retracta in March, May, and August of 2014. Dead salps were placed in small $(\sim 5 \times 5 \mathrm{~cm}) 200 \mu \mathrm{m}$ mesh bags submerged in a large beaker in the dark with a continuous flow-through of surface seawater $\left(19-23^{\circ} \mathrm{C}\right)$ for the duration of the experiment, simulating the decomposition process in warm epipelagic waters with the resident microbial assemblage. Several salps were removed at each time point from their mesh bags and "sacrificed" from the experiment to be frozen for analysis onshore. This removal occurred at regular intervals ( 8-12 hours) until all salps were either removed or completely decomposed. Once onshore, salp remains were placed in a drying oven at $60^{\circ} \mathrm{C}$ for at least one week and then weighed. Initial salp dry weight (i.e., $\mathrm{T}_{0}$ ) was estimated from length measurements of freshly caught, whole salps using published salp live length to carbon weight regression equations for each species (see Table 5.3 in Madin \& Deibel 1998, and references therein). Occasionally, the measured dry weights of the initial, undecomposed salps were consistently different from the dry weights calculated by the regression equations. When this occurred, a correction factor was applied to all salps in that experiment by adding or subtracting the difference between the mean calculated and mean measured dry weights of the time zero $\left(\mathrm{t}_{0}\right)$ salps. Decay rate of 
salp carcasses was calculated by plotting the percent remaining of initial salp dry weight over time and

161 fitting a first-order exponential decay curve:

162

$\mathrm{P}=\mathrm{a} * \mathrm{e}^{\left(-\mathrm{k}^{*} \mathrm{t}\right)}$

163

Where ' $\mathrm{P}$ ' is percent of starting salp dry weight remaining, ' $\mathrm{a}$ ' is the percent remaining at time zero $\mathrm{t}_{0}$, ' $\mathrm{k}$ ' is the decay constant, and ' $t$ ' (hours) is time from the start of the experiment. Similar experiments were carried out at $8^{\circ} \mathrm{C}$ using water collected from $1000 \mathrm{~m}$, to simulate meso- and bathypelagic conditions. For these experiments, instead of water continuously flowing through the decomposition chamber, carcasses were placed in $4 \mathrm{~L}$ bottles in a refrigerator, and the water in each bottle was replenished every 12 hours.

Model development

We developed a one-dimensional model to calculate salp contributions to total vertical carbon flux (Figure 1). Fecal pellet production, grazing, production of carcasses, and respiration at depth was calculated daily for each species' biomass. Data forced into the model included biological,

172 environmental, and process rate data (e.g., salp biomass, temperature, primary production) collected 173 through the BATS program (http://bats.bios.edu/), previously published rates of salp metabolic and export 174 processes (fecal pellet production, respiration, and DOC excretion), as well as results from the above 175 sinking and decomposition experiments. Salp 'blooms' were defined as in Stone and Steinberg (2014), 176 i.e., when total salp biomass is in the top $10 \%$ of all observations. at the BATS site as detailed in Stone and Steinberg (2014). Species-specific biomass was averaged from duplicate day and night tows, with only the night tow biomass used for species that exhibited diel-vertical migration. Salp blooms are generally short-lived, and typically do not remain at high abundance for several months. Because the duration of each salp bloom could not be accurately estimated from monthly sampling, the biomass data were linearly interpolated between each sampling date to give a biomass estimate for each day from April 15, 1994 to November 14, 2011. This was done for each of the 21 
species and 4 higher taxa categories (Pegea sp., Salpidae, Salpa sp., and Thalia sp.) in the dataset; the 25 biomass time series were then used to force the flux model. Based on Stone and Steinberg (2014), all species were split into those which exhibited diel vertical migration (DVM; Salpa fusiformis, Wheelia cylindrica, Iasis zonaria, S. aspera, and Ritteriella retracta) and those that did not exhibit DVM (Brooksia rostrata, Cyclosalpa affinis, C. floridana, C. pinnata, C. polae, Helicosalpa virgula, Ihlea punctata, Pegea bicaudata, P. confoederata, P. socia, Pegea sp., S. maxima, Salpa sp., Salpidae, Thalia cicar, T. democratica, T. orientalis, Thetys vagina, and Traustedtia multitentaculata). For each DVM species, an overall average migrating proportion of the biomass was calculated by dividing each sampling date's day biomass by night biomass and subtracting from 1 to obtain a percentage of biomass that was migrating. These percentages were then averaged for each species across the entire time series. For nonDVM species, we calculated the amount of carbon reaching 200m from both fecal pellet production (FPP) and from sinking of carcasses (i.e., the 'passive flux'). For DVM species, we additionally calculated respiration and dissolved organic carbon (DOC) excretion while at depth (i.e., the 'active flux').

Fecal pellet production, sinking of dead carcasses, respiration and DOC excretion at depth, and grazing were all resolved daily from April 1994 to November 2011 as described in the following sections. For fecal pellet production, species-specific FPP rates were used when available from the literature; for species without a specific rate, rates from the same genus or family were averaged (Supplementary Table 1; Deibel 1982, Madin 1982, Mullin 1983, Small et al. 1983, Cetta et al. 1986, Andersen 1985, Huntley et al. 1989, Madin and Purcell 1992, Sreekumaran Nair et al. 1995). Fecal pellet decomposition was based on rates averaged from Caron et al. (1989), who measured the loss of ash free dry weight over a 10-day experiment. Based on literature values for fecal pellet sinking rates (Bruland and Silver 1981, Caron et al. 1989, Phillips et al. 2009), salp fecal pellets would reach the Sargasso Sea floor well within 10 days. Because the experiments in Caron et al. (1989) looked at fecal pellet decomposition over a total of 10 days through a temperature gradient $\left(1\right.$ day at $22^{\circ} \mathrm{C}$ followed by 9 days at $\left.5^{\circ} \mathrm{C}\right)$ and did not measure pellet decomposition at only one temperature, we were unable to separately model the decomposition taking 
place in the warm surface waters from that at colder depths. Thus, we applied the total 10-day

decomposition measured by Caron et al. (1989), and no additional decomposition parameter was applied after the fecal pellets reached $200 \mathrm{~m}$. Because fecal pellets would sink below 200m much more quickly than 10 days, our estimates are conservative. For DVM species, we assumed the following: 1) FPP was the same in the surface waters and at depth, as salps with full guts would continue to produce fecal pellets after migrating to depth for some time and would not immediately begin producing them again after returning to the surface, 2) migrators spent 12 hours per day above $200 \mathrm{~m}$ and 12 hours per day below 200m, and 3) while physical breakup or resuspension of fecal material may occur, we had no reliable estimates of these processes, and they were not included in the model.

We modeled carcass sinking and decomposition by incorporating the experimentally-determined rates for each species (Figure 2 and Table 1), and averaging across genus or family when species-specific rates were not available. Daily biomass of each species and life stage was multiplied by the proportion dying each day (the mortality rate), which gave a biomass of dead salps produced each day. All salps were conservatively assumed to have died at the surface, and the amount of time required to sink $200 \mathrm{~m}$ was calculated by using the species-specific corrected rates in Figure 2. The decomposition equations in Table 1 were then used with the time required to sink $200 \mathrm{~m}$ to determine the sinking carcass biomass. The monthly proportion of salp biomass in each life stage (blastozooid or oozoid) was calculated from BATS count data, and then linearly interpolated to obtain a daily value. Life spans were estimated as 3 days for Thalia blastozooids, 14 days for Thalia oozoids, 15 days for all other salp blastozooids, and 30 days for all other salp oozoids (Henschke et al. 2011, Deibel and Lowen 2012). Daily death rates were estimated as the proportion of the population reaching the end of its lifespan each day; for example, the 14-day lifespan of Thalia oozoids translates as 1/14 of Thalia oozoid biomass dying each day. For DVM species, we estimated that half of the population died above $200 \mathrm{~m}$, and half below $200 \mathrm{~m}$. Since we did not measure decomposition at colder temperatures or under increased pressure at depth, we calculated biomass of carcasses produced below 200m (reaching depths of 300m, 500m, 1500m, and 3200m) by 
applying the decomposition rates of Lebrato et al. (2011, 2013a) separately to $T$. democratica (due to slower sinking speeds of this species), and then to all other species combined. We assumed a constant temperature of $18^{\circ} \mathrm{C}$ from $200-500 \mathrm{~m}, 8^{\circ} \mathrm{C}$ from $500-1000 \mathrm{~m}, 5^{\circ} \mathrm{C}$ from $1000-1500 \mathrm{~m}$, and $3^{\circ} \mathrm{C}$ from 1500 3200m (http://batsftp.bios.edu/BATS/ctd/).

Salp active transport-respiration and DOC excretion at depth- was calculated for the five DVM species while they were below $200 \mathrm{~m}$. One rate for each parameter was applied to all species. An average respiration rate $\left(2.2 \%\right.$ body $\left.\mathrm{C} \mathrm{h}^{-1}\right)$ was calculated from data compiled in Madin and Purcell (1992) and Cetta et al. (1986). There is no published DOC excretion rate of salps, thus DOC excretion rate for this model was averaged from those of other gelatinous zooplankton (ctenophores and cnidarians) in Condon et al. (2011) (0.182 $\mathrm{mgC} \mathrm{h}^{-1} \mathrm{~g}$ dry body weight $\left.{ }^{-1}\right)$. the average carbon biomass of phytoplankton $0-140 \mathrm{~m}$, as phytoplankton biomass is not significant below $140 \mathrm{~m}$. Both daily chlorophyll $a$ and primary production were linearly interpolated from the monthly BATS sampling (http://batsftp.bios.edu/BATS/bottle/bats_pigments.txt and http://batsftp.bios.edu/BATS/production/bats_production.dat). Phytoplankton carbon biomass was calculated by multiplying the daily chlorophyll $a$ concentration by a seasonal carbon to chlorophyll ratio (C:Chl). These $\mathrm{C}: \mathrm{Chl}$ ratios $(\mathrm{g} / \mathrm{g})$ were calculated from seasonal averages of BATS chlorophyll $a$ concentration and average seasonal values of phytoplankton carbon from Wallhead et al. (2014), and were as follows (months in parentheses): 52 - winter (JFM), 60 - spring (AMJ), 52 - summer (JAS), and 47 fall (OND). Species-specific clearance rates were used when available; otherwise, average rates for genus or family were used (Supplementary Table 1; Harbison and Gilmer 1976, Harbison and McAlister 1979, Deibel 1982, Mullin 1983, Madin and Cetta 1984, Andersen 1985, Deibel 1985, Reinke 1987, Madin and Purcell 1992, Sreekumaran Nair et al. 1995, Vargas and Madin 2004, Hereu et al. 2010). Because salps are considered non-discriminant filter feeders (Madin 1974) and only cease feeding when their internal filters become clogged at very high phytoplankton concentrations (i.e., above $\sim 1 \mathrm{ug} \operatorname{chl} a \mathrm{~L}^{-1}$, Andersen 
1985 and Harbison et al. 1986; concentrations rarely reached at BATS), we assumed clearance rates to be constant regardless of phytoplankton concentration. While some DVM species may migrate at different times of the day (Madin et al. 1996), further research is needed to quantify these differences, and all DVM species were assumed to graze 12 hours each 24-hr period in surface waters. All salp grazing rates were based on phytoplankton standing stocks, and FPP rates for this model were independent of calculated grazing (see above). If grazing rates were to be used in an energetic model or to calculate FPP, consumption of microzooplankton (such as dinoflagellates and ciliates shown in Vargas and Madin 2004) would also need to be taken into consideration.

Sediment trap flux

Sediment trap POC flux data $\left(\mathrm{mgC} \mathrm{m} \mathrm{may}^{-1}\right)$ for sediment traps at $150 \mathrm{~m}, 200 \mathrm{~m}$, and $300 \mathrm{~m}$ from April 1994 to November 2011 were downloaded from the BATS database (bats.bios.edu). Mean POC flux for traps at 500m (1984-1986, 1989-1982, and 1997-1998), 1500m (1984-1992, and 1997-1998), and 3200m (1978-1998) was calculated from Table 1 in Conte et al. 2001.

\section{Results}

Sinking and Decomposition rates

Mean salp carcass sinking rate was measured for 8 species ranging in average size from $8 \mathrm{~mm} T$. democratica to $30 \mathrm{~mm}$ S. maxima. Sinking rates ranged from 414-871 $\mathrm{m} \mathrm{d}^{-1}$ and 467-1002 $\mathrm{m} \mathrm{d}^{-1}$, before and after correcting for wall-interaction effects, respectively (Fig. 2), with a mean (corrected) sinking rate across all species of $727 \mathrm{~m} \mathrm{~d}^{-1}(\mathrm{n}=293)$. The corrected rates were used throughout the model calculations. There were weak linear correlations between salp length vs. sinking rate $\left(\mathrm{p}<0.001 ; \mathrm{r}^{2}=0.21\right)$ and water density vs. sinking rate $\left(\mathrm{p}>0.05 ; \mathrm{r}^{2}<0.01\right)$. We posit that sinking rate was not dependent on water density due to the high water content of salp carcasses, and thus there was an equally proportional change in their body density as in the surrounding seawater after adjusting to the new temperature. However, there were 
significant differences in sinking rate between individual species, with Wheelia cylindrica $\left(1002 \mathrm{~m} \mathrm{~d}^{-1}\right)$ and Salpa maxima $\left(927 \mathrm{~m} \mathrm{~d}^{-1}\right)$ sinking faster than the two slowest sinking species, Cyclosalpa polae $\left(526 \mathrm{~m} \mathrm{~d}^{-1}\right)$ and Thalia democratica $\left(467 \mathrm{~m} \mathrm{~d}^{-1}\right)($ Kruskal-Wallis ANOVA on ranks; Figure 2). Thus, the average rates of similar taxa were used in model calculations, and sinking was not based on salp size or variance in water density.

Species-specific decomposition rates were calculated for species with sufficient replication to obtain a significant exponential decay curve (I. zonaria, S. fusiformis, and T. democratica), while an average of all of the warm-water experiments was used to fit a decay curve for the rest of the species (Table 1; Figure 3). No measurable decomposition occurred over 3 days during the cold-water experiments. As described in the methods, actual measured salp weights at $\mathrm{t}_{0}$ were used to adjust the calculated starting weights. This method was successful, as measured/modeled weight ratio at $\mathrm{t}_{0}$ was distributed normally (Shapiro-Wilk p=0.132) and the mean was $1.07( \pm 0.27 \mathrm{SD})$. Modeled salp decomposition was rapid within the first several hours, with $50 \%$ of the starting dry weight lost after only 8 hours. Decomposition of the subsequent $49 \%$ took much longer, 44 additional hours, with some salp biomass still present 56 hours into the experiment.

\section{Grazing Model}

Total daily salp grazing was, on average, $0.05 \mathrm{mg} \operatorname{chl} a \mathrm{~m}^{-3} \mathrm{~d}^{-1}( \pm 0.003$ standard error, SE), or $26 \%$ of the chlorophyll biomass over the $17+$ year model run (6,423 days). However, median daily salp grazing was only $0.004 \mathrm{mg} \mathrm{chl} a \mathrm{~m}^{-3} \mathrm{~d}^{-1}$, or $2 \%$ of the chlorophyll biomass; this difference being driven by periodically high salp abundances. Likewise, while salp grazing impact was typically low (an average of $3.9 \%$ of the chlorophyll biomass during non-bloom salp abundances), during salp blooms, calculated grazing was an average of $220 \%$ of the phytoplankton standing stock present in epipelagic waters (Figure 4A). Grazing was also seasonally variable, with elevated mean grazing in spring and early summer (March-June; $6.5 \mathrm{mg} \mathrm{C} \mathrm{m}^{-2} \mathrm{~d}^{-1}$ ) compared to the rest of the year (July-February; $0.7 \mathrm{mg} \mathrm{C} \mathrm{m}^{-2} \mathrm{~d}^{-1}$ ). 
Annual grazing across the time series was a median of $17 \%$ of the annual primary production (Figure 4B), with annual grazing exceeding $100 \%$ of the primary production in 1999, 2002, and 2008. Additionally, the proportion of primary production exported by salps was low $(<0.5 \%)$ for much $(86 \%)$ of the time series, but increased to as much as $35 \%$ during large blooms (Figure 5B). On average, $0.5 \%$ of all primary production at BATS, from April 1994 to November 2011, was exported to below 200m by salps.

\section{Flux Model Results}

The daily salp-mediated carbon flux to $200 \mathrm{~m}$ for each of 25 salp taxa from April 15, 1994 to November 15, 2011 was computed in the model. This included fecal pellet production (FPP) and export, sinking of salp carcasses, and respiration and DOC excretion by DVM at depth. The total carbon flux was generally low, with salp-mediated carbon export less than $1.0 \mathrm{mgC} \mathrm{m}^{-2} \mathrm{day}^{-1}$ in $76 \%$ of the time series. However, due to the population dynamics of salps, this low baseline was punctuated with large salp blooms causing spikes in the flux of several orders of magnitude (Figure 5). These salp blooms cumulatively accounted for $79 \%$ of the total modeled salp POC flux across the time series, over half of which was produced by the blooms in 1999,2008 , and 2011. Total salp-mediated export to $200 \mathrm{~m}$ was highly correlated with total salp grazing (Pearson's correlation coefficient $=0.93, \mathrm{p}<0.001$ ), and averaged across the entire time series salp carbon flux was $1.6 \%$ of the total carbon grazed by salps. The average daily salp-mediated carbon export across the time series was $2.3 \mathrm{mgC} \mathrm{m}^{-2}$ day $^{-1}$ and the median flux was $0.4 \mathrm{mgC} \mathrm{m}^{-2} \mathrm{day}^{-1}$. The largest proportion of salp-mediated carbon export came from fecal pellets, with an annual average of $78 \%\left(586 \mathrm{mgC} \mathrm{m}^{-2} \mathrm{year}^{-1}\right)$ (Table 2). The second largest contribution to export was from respiration at depth $\left(19 \% ; 139 \mathrm{mgC} \mathrm{m}^{-2}\right.$ year $\left.{ }^{-1}\right)$, followed by sinking of carcasses (3\%; $23 \mathrm{mgC} \mathrm{m}^{-2}$ year $\left.^{-1}\right)$, and DOC excretion at depth $\left(<0.1 \% ; 0.1 \mathrm{mgC} \mathrm{m}^{-2}\right.$ year $\left.^{-1}\right)$ (Table 2).

Seasonal trends in salp carbon flux varied according to the source of the flux, and trends were slightly different dependent upon whether mean or median values of export were considered (Fig. 6). As salp export is several orders of magnitude higher during periodic salp blooms, mean values were much 
higher than median values for much of the model output. Mean export due to salp fecal pellets was

332 elevated in spring and early summer (March-June), while respiration and carcass carbon flux were more

333 elevated in late summer (July-September) (Figure 6A). Median fecal pellet and carcass fluxes were

334 elevated through all of the spring and summer (February-September), while median respiration peaked in

335 late winter (February and March) and summer (July-September) (Figure 6B). DOC excretion was

336 negligible in all seasons. Both mean and median total salp carbon flux were higher in spring and summer

337 than in fall and winter.

Five species accounted for $96 \%$ of the total salp-mediated carbon flux at BATS, with Thalia democratica contributing the most, followed by Salpa aspera, S. fusiformis, Iasis zonaria, and Wheelia cylindrica (Figure 7A). The other 20 species and taxa combined contributed the remaining 4\%. This was calculated by summing the total flux contributed by each species for the entire time series. However, when each species' annual total contribution was averaged for each year of 1995-2010, S. fusiformis was the largest contributor to flux, followed by T. democratica, S. aspera, W. cylindrica, and I. zonaria (Figure 7B).

Overall, total annual salp carbon flux ranged widely, from 97 to $4580 \mathrm{mgC} \mathrm{m}^{-2} \mathrm{y}^{-1}$ in 1997 and 1999, respectively (Figure 8A), with a mean and standard deviation of $748 \pm 1133 \mathrm{mgC} \mathrm{m}^{-2} \mathrm{y}^{-1}$ for the time series. Annual BATS 200m sediment trap flux ranged from 5260 to $9710 \mathrm{mgC} \mathrm{m}^{-2} \mathrm{y}^{-1}$ in 2005 and 2002 , respectively (Figure 8B) with a mean and standard deviation of $7530 \pm 1050 \mathrm{mgC} \mathrm{m}^{-2} \mathrm{y}^{-1}$. Annual salp-mediated export flux was equivalent to a mean of $10 \% \pm 15$ (range 1-60\%) of the $200 \mathrm{~m}$ sediment trap POC flux over the time series (Figure 8C).

While there was no consistent long-term change in total salp C export over the time series $\left(\mathrm{r}^{2}<\right.$ 0.01), there was a periodicity to export. We performed spectral analysis on monthly totals of salp C export to 200m, and the highest spectral densities were found at 9, 12, and 36 months (approximate p- 
cycles on seasonal (9 months between the late summer and spring blooms), annual, and interannual time scales, respectively.

357

358

359

360

361

362

Relatively little of the total salp-exported carbon was lost as it sank through the water column (Figure 9), due to fast sinking and slow decomposition of fecal pellets and carcasses. Average daily salp carbon flux at $200 \mathrm{~m}$ across the time series was $2.3 \mathrm{mgC} \mathrm{m}^{-2}$ day $^{-1}$ and only attenuated to $1.9 \mathrm{mgC} \mathrm{m}^{-2}$ day ${ }^{1}$ at $3200 \mathrm{~m}$. This was a decrease of only $19 \%$, whereas average daily POC flux captured in sediment traps decreased by $92 \%$ between $200 \mathrm{~m}$ and $3200 \mathrm{~m}$ (from 20.6 to $1.7 \mathrm{mgC} \mathrm{m}^{-2}$ day $^{-1}$ ). At $3200 \mathrm{~m}$, calculated salp carbon (mostly from fecal pellets) was equivalent to $109 \%$ of the POC collected in the sediment traps (Figure 9).

\section{Discussion}

Carcass Sinking Rates

Salp carcass sinking rates varied between 467 and $1002 \mathrm{~m} \mathrm{~d}^{-1}$, similar to the few previously published measurements. Moseley (1880) recorded a sinking rate of $\sim 860 \mathrm{~m} \mathrm{~d}^{-1}$ for an unknown species of salp, and Wiebe et al. (1979) reported Salpa aspera carcasses sank 240-480 $\mathrm{m} \mathrm{d}^{-1}$. Lebrato et al. (2013a) found Salpa thompsoni carcasses sink 800-1700 $\mathrm{m} \mathrm{d}^{-1}$, and other gelatinous zooplankton, including Cyanea sp., Pelagia noctiluca, Mnemiopsis leidyi, and Pyrosoma atlanticum, had average sinking rates of 400-1500 $\mathrm{m} \mathrm{d}^{-1}$. While Lebrato et al. (2013a) found a positive relationship between salp biovolume and sinking rate, we found no significant relationship overall between salp length and sinking rate but that there were some significant differences between species. In our study the smallest species of salp (Thalia democratica) did have the slowest sinking rate. Differences between species in sinking rate other than body size could be related to different relative sizes of the dense, phytoplankton-filled gut or sinking orientation of each individual salp. 


\section{Decomposition rates}

Decomposition rates of salps were fast enough that while much of the carcass carbon would be exported out of the epipelagic, very little would reach bathypelagic depths before complete decomposition. We found the exponential decay constant ' $k$ ' of all salp species combined to be $2.2 \mathrm{~d}^{-1}$ at $21{ }^{\circ} \mathrm{C}$, which is close to the calculated $k$ of $2.9 \mathrm{~d}^{-1}$ for all gelatinous zooplankton using Equation 2 in Lebrato et al. (2011). However, the decay constant for Thalia democratica $(k=14.5)$ was much higher than that calculated for all gelatinous zooplankton in Lebrato et al. (2011). While this may be due to a higher surface area-to-volume ratio of the small T. democratica compared to larger salps, decomposition of T. democratica was included in Equation 2 of Lebrato et al. (2011), albeit at a lower experimental temperature of $16.5^{\circ} \mathrm{C}$ (Sempere et al. 2000). Sempere et al. (2000) observed that salp carcasses consist of a quickly decomposing, labile fraction and a more slowly decomposing fraction, which is consistent with our experimental results showing exponential decay.

While slow-sinking salp species or small individuals, which make up the majority of salp biomass at BATS, may decompose before reaching the benthos, less common blooms of larger and faster sinking species would be able to reach the deep sea. Additionally, DVM species could die at their daytime mesopelagic residence depth, and thus be more likely to reach the benthos since much of the decomposition occurs in warmer surface waters. While we used a depth horizon of salp DVM of 200m for the purpose of our model, at least one species of salp in the North Atlantic subtropical gyre (Salpa aspera) migrates to depths $>800 \mathrm{~m}$ (Wiebe et al. 1979), where temperatures are $\sim 10^{\circ} \mathrm{C}$ and decomposition much slower. Thus, our estimates of salp carcass carbon export to the deep sea are likely conservative.

\section{Grazing}

Salp grazing had relatively low impact on phytoplankton standing stock and primary production (PP) for much of the year, but periodically extremely high grazing during salp blooms resulted in demand often exceeding phytoplankton supply, with grazing over 100\% phytoplankton standing stock and PP. 
Similarly, salp grazing in the Humboldt Current averaged $16 \%$ but was up to $60 \%$ of PP (Gonzalez et al. 2000), off NW Spain averaged 7\% of chlorophyll standing stock but was as much as $77 \%$ (Huskin et al. 2003), in the California current system ranged from $<1$ to $>100 \%$ of daily PP and phytoplankton biomass (Hereu et al. 2006), and in the Eastern Tropical North Pacific ranged from 0.01 to $3.5 \%$ of chlorophyll standing stock each day (Hereu et al. 2010). The high grazing impact seen during salp blooms would only be sustained for a short time before phytoplankton standing stocks were depleted, suggesting bottom-up control and a mechanism for the rapid demise of salp blooms (Henschke et al. 2014).

Seasonal patterns of grazing by salps were similar to other mesozooplankton at BATS, with elevated grazing in spring compared to the rest of the year. Total mesozooplankton $(>64 \mu \mathrm{m})$ grazing in the Sargasso Sea was $88 \mathrm{mg} \mathrm{C} \mathrm{m}^{-2}$ day $^{-1}$ in March/April 1990 (82\% of PP) and $13 \mathrm{mg} \mathrm{C} \mathrm{m}^{-2}$ day $^{-1}$ in August 1989 (25\% of PP) (Roman et al. 1993). In both seasons, salps contributed a similar proportion to the total mesozooplankton grazing, with average salp grazing in both March/April and August 6\% of the total grazing reported in Roman et al. (1993).

Salp-mediated carbon flux

On average, total salp-mediated $\mathrm{C}$ flux is significant compared to the POC flux measured by sediment traps at $200 \mathrm{~m}$, consistent with previous studies of fecal pellet contributions to carbon flux in the Sargasso Sea (Steinberg et al. 2012) and the temperate North Pacific (Iseki 1981). Annual average salp fecal pellet flux in our study is equivalent to $7.8 \%$ of sinking trap POC flux and active transport by DVM is $1.9 \%$ of trap POC flux. During blooms, however, salps account for a higher portion of C flux out of the euphotic zone, and high-abundance years can produce total salp-mediated carbon fluxes up to 60\% (as in 1999) of trap POC flux at 200m. These high fluxes are mostly a result of Thalia democratica blooms, where daily total export fluxes reached up to $144 \mathrm{mg} \mathrm{C} \mathrm{m}^{-2} \mathrm{~d}^{-1}$, and these bloom fluxes are more comparable to those found in coastal regions. For example, Madin et al. (2006) found FPP by Salpa 
425

aspera in the summer in slope waters off New England was 5-91 $\mathrm{mgC} \mathrm{m}^{-2}$ night $^{-1}$, and Phillips et al. (2009) found S. thompsoni produced up to $20 \mathrm{mg} \mathrm{C} \mathrm{m}^{-2}$ day $^{-1}$ in fecal pellets off the Antarctic Peninsula. Dissolved organic carbon flux was low compared to other sources of salp carbon export, likely because the most abundant species, Thalia democratica, did not vertically migrate, and any DOC excretion by non-DVM species would remain in the surface waters. However, uncertainties in our applied weight-specific salp DOC excretion rate could lead to underestimates of DOC export. There are limited measurements of DOC excretion by zooplankton, and none for salps. We used DOC excretion rates based on those measured for gelatinous zooplankton by Condon et al. (2011). Kremer (1977) found that DOC excretion by the ctenophore Mnemiopsis leidyi is equal to $61 \%$ of respiration, and Steinberg et al. (2000) found that average DOC excretion was $31 \%$ of respiration for several migrating crustacean zooplankton taxa and a gelatinous polychaete. Using an intermediate DOC excretion rate of $40 \%$ of respiration, our estimates of salp DOC export at BATS would increase to $56 \mathrm{mgC} \mathrm{m}^{-2} \mathrm{y}^{-1}$, or $7 \%$ of the yearly total salp-mediated carbon flux. Experimental measurements of salp DOC excretion rates are needed to resolve this issue.

Seasonality in average carbon export by salps can be explained by seasonality in salp blooms, with the peaks driven by periodic large blooms. The general pattern of higher flux in late winter and spring, and lower flux in late summer and fall, is consistent with the general pattern of primary production at BATS (Steinberg et al. 2001, Lomas et al. 2013). Higher respiratory DVM flux in the early spring and late summer is due to seasonal increases in large, vertically migrating species like S. fusiformis in the spring and W. cylindrica in the late summer (Stone and Steinberg 2014). Because biomass of salps increases by several orders of magnitude during blooms, average salp fluxes are often driven by a few large blooms over the time series. Thus when summing across an entire year, the difference between mean and median may not be great; however, when summing across smaller time periods, such as a single season, the difference may be large. 

the salp, due to increases in FPP and respiration rates with body size, and whether they vertically migrate.

451 Vertically migrating species (Salpa aspera, S. fusiformis, Wheelia cylindrica, Iasis zonaria, and

452 Ritteriella retracta) produce fecal pellets and carcasses and respire at depths already below the

453 pycnocline, not only decreasing the distance they have to sink, but also spending less time in warmer

454 surface waters where bacterial decomposition is faster. Carcasses from small species, such as Thalia sp., 455 not only sink more slowly, but also decompose more rapidly. Thus, a small species such as $T$.

democratica would overall export less carbon than an equivalent biomass of a larger, vertically migrating species such as $S$. aspera. However, in the Sargasso Sea this difference is often masked by the considerably higher biomass of $T$. democratica blooms compared to all other species.

There were no significant long-term trends in total annual salp C export, which is dependent on the frequency and size of blooms, and peaks in export every three years is consistent with a three-year cycle of Thalia democratica peak biomass (Stone and Steinberg 2014). However, there is a recorded long-term increase in total sinking POC flux to $150 \mathrm{~m}$ as measured by sediment traps during the high production winter-spring transition period at BATS (Lomas et al. 2010; although there was no significant increase when averaged over the entire year). Steinberg et al. (2012) also calculated an increase in both fecal pellet POC export and active $\mathrm{C}$ transport by diel migrating zooplankton over time due to a long-term increase in BATS mesozooplankton biomass (including an increase in DVM zooplankton biomass). This contrast between increases in winter-spring period trap flux and no change in calculated salp flux may indicate that other, non-salp-mediated pathways of export are as efficient as salp-mediated ones during this period. Comparisons between measured trap flux and calculated flux are further complicated by sediment traps not reliably capturing exported particles from spatially and temporally variable salp blooms.

Salps contribute an increasingly higher proportion of C export with increasing depth compared to sinking POC flux measured with sediment traps. At 200m, salp flux only accounts for $11 \%$ of the daily 
474

475

476

477

478

479

480

481

482

483

484

485

486

487

488

489

490

491

492

493

494

495

496

497

POC flux on average. Comparatively, average daily POC flux at $3200 \mathrm{~m}$ of $1.7 \mathrm{mg} \mathrm{C} \mathrm{m}^{-2} \mathrm{day}^{-1}$ at BATS (Conte et al. 2001) is less than our calculated salp flux of $1.9 \mathrm{mg} \mathrm{C} \mathrm{m}^{-2}$ day $^{-1}$ at that same depth. This high amount of salp carbon reaching the deep sea has been directly observed on one occasion in the northeastern Pacific, where a Salpa sp. bloom deposited large amounts of fecal pellets and carcasses to the seafloor ( 4000m) (Smith et al. 2014). However, Shatova et al. (2012) quantified zooplankton fecal pellets in traps at 500,1500, and 3200m at BATS in 2007, and found that FP carbon only contributed $4.6 \%$ of the total carbon flux at $3200 \mathrm{~m}$, much lower than our calculated values. Additionally, they found that fecal pellets are subject to high rates of recycling and repackaging in the deep water column. Our higher estimates of deep salp export may be explained by: including carcasses-which baffles on sediment traps are likely to exclude, including DVM-which is not measured by sediment traps, and not including scavenging and consumption of salp fecal pellets and carcasses.

\section{Summary and Conclusion}

Salp populations in the oligotrophic Sargasso Sea play an important role in transporting carbon from the epipelagic zone to the deep sea. The primary source of salp-mediated carbon flux is the sinking of fecal pellets, but contributions from respiration at depth by diel vertically migrating species and sinking of salp carcasses are also important. Salp carbon flux is relatively low for much of the year, punctuated by several orders of magnitude higher fluxes during periodic population blooms, especially in spring. Salp grazing follows a similar pattern, with relatively low levels of grazing interspersed with removal of $100 \%$ of phytoplankton standing stock and PP during blooms. Thalia democratica is the highest contributor to salp flux, but due to its small size and absence of vertical migration, most of this species' contribution is from sinking fecal pellets. Larger species that vertically migrate (such as Salpa fusiformis, S. aspera, Iasis zonaria, and Wheelia cylindrica) respire carbon consumed in the epipelagic in the mesopelagic zone, and produce carcasses at depth that can reach the benthos (Cacchione et al. 1978, 
Wiebe et al 1979). While low and high periods of salp flux average out to be a small percentage of total flux captured annually in sediment traps at 200m, salp flux contributes a much higher percentage of the total flux in the bathypelagic zone, mostly due to slow decomposition and fast sinking of fecal pellets and

501

502

503

504

505

506

507

508

509

510

511

512

513

514

515

516

517

518

519 carcasses.

Future changes in the diversity and abundance of salp populations could affect the efficiency of the biological pump in the Sargasso Sea. As shown in Stone and Steinberg (2014), Thalia democratica and Cyclosalpa polae populations have increased, and T. democratica biomass was three-fold higher within cyclonic eddies than outside eddies. If these population increases continue, carbon flux would significantly increase, especially to the bathypelagic and benthos-carbon sequestration depths.

Acknowledgements

We are grateful to the many Bermuda Atlantic Time-series Study (BATS) technicians involved in the sampling and maintenance of the zooplankton time series over the last 2 decades. We appreciate the support of the officers and crew of the R/V 'Weatherbird II' and the R/V 'Atlantic Explorer' for help with sample collection. Special thanks go to Mark Brush for assistance with model development. The BATS zooplankton time series was initially funded by National Science Foundation (NSF) grant OCE-9202336 to L. P. Madin, and continued by the BATS program through the NSF Chemical and Biological Oceanography programs (OCE-9301950, OCE- 9617795, and OCE-0326885), and through OCE0752366 and OCE-1258622 to D.K.S., which funded this current effort. Data collected onboard the 'Trophic BATS' cruise was supported by OCE -1090149 to R. Condon. This paper is Contribution No. xxxx of the Virginia Institute of Marine Science, College of William \& Mary. 
521 Álvarez-García FJ, Ortiz-Bevia MJ, Cabos-Narvaez WD (2011) On the structure and teleconnections of

522 North Atlantic decadal variability. J Clim 24: 2209-2223

523 Andersen V (1985) Filtration and ingestion rates of Salpa fusiformis Cuvier (Tunicata: Thaliacea): Effects

524 of size, individual weight and algal concentration. J Exp Mar Biol Ecol 87: 13-29

525

526

527

528

529

530

531

532

533

534

535

536

537

538

539

540

541

542

543

544

545

546

547

548

549

550

551

552

553

Andersen V, Nival P (1988) A pelagic ecosystem model simulating production and sedimentation of biogenic particles: role of salps and copepods. Mar Ecol Prog Ser 44: 37-50

Atkinson A, Siegel V, Pakhomov E, Rothery P (2004) Longterm decline in krill stock and increase in salps within the Southern Ocean. Nature 432: 100-103

Bone Q, Carre C, Chang P (2003) Tunicate feeding filters. J Mar Biol Assoc UK 83: 907-919

Bruland KW, Silver MW (1981) Sinking rates of fecal pellets from gelatinous zooplankton (Salps, Pteropods, Doliolids). Mar Biol 63: 295-300

Cacchione DA, Rowe GT, Malahoff A (1978) Submersible investigation of outer Hudson submarine canyon. In: Stanley DJ, Kelling F (eds) Sedimentation in Submarine Canyons, Fans, and Trenches. Dowden, Hutchinson \& Ross, Inc. Stroudsburg, PA, p42-50

Caron DA, Madin LP, Cole JJ (1989) Composition and degradation of salp fecal pellets: implications for vertical flux in oceanic environments. J Mar Res 47: 829-850

Cetta CM, Madin LP, Kremer P (1986) Respiration and excretion by oceanic salps. Mar Biol 91: 529-537

Condon RH, Duarte CM, Pitt KA, Robinson KL, Lucas CH, Sutherland KR, Mianzan HW, Bogeberg M, Purcell JE, Decker MB, Uye S, Madin LP, Brodeur RD, Haddock SHD, Melej A, Parry GD, Eriksen E, Quiñones J, Acha M, Harvey M, Arthur JM, Graham WM (2012) Recurrent jellyfish blooms are a consequence of global oscillations. PNAS 110(3): 1000-1005

Condon RH, Steinberg DK, del Giorgio PA, Bouvier TC, Bronk DA, Graham WM, Ducklow HW (2011) Jellyfish blooms result in a major microbial respiratory sink of carbon in marine systems. PNAS 108(25): 10225-10230

Conte MH, Ralph N, Ross EH (2001) Seasonal and interannual variability in deep ocean particle fluxes at the Oceanic Flux Program (OFP)/Bermuda Atlantic Time Series (BATS) site in the western Sargasso Sea near Bermuda. Deep-Sea Res II 48: 1471-1505

Conte MH, Weber JC (2014) Particle flux in the Deep Sargasso Sea: The 35-year Oceanic Flux Program time series. Oceanography 27(1): 142-147

Deibel D (1982) Laboratory-measured grazing and ingestion rates of the salp, Thalia democratica Forskal and Dolioletta gegenbauri Uljanin (Tunicata, Thaliacea). J Plankton Res 4: 143-153

Deibel D (1985) Clearance rates of the salp Thalia democratica fed naturally occurring particles. Mar Biol 86: $47-54$ 
572

573

574

575

576

577

578

579

580

581

582

583 584

585 586

Deibel D, Lowen B (2012) A review of the life cycles and life-history adaptations of pelagic tunicates to environmental conditions. ICES J of Mar Sci 69(3): 358

Fuller WA (1996) Introduction to Statistical Time Series. John Wiley \& Sons, New York, NY, pp. 698

Godeaux J, Bone Q, Braconnot JC (1998) Anatomy of Thaliacea. In: Bone Q (ed) The biology of pelagic tunicates. Oxford University Press, New York, NY, p 1-24

Goldthwait SA, Steinberg DK (2008) Elevated biomass of mesozooplankton and enhanced fecal pellet flux in cyclonic and mode-water eddies in the Sargasso Sea. Deep-Sea Res II 55: 1360-1377

González HE, Sobarzo M, Figueroa D, Nöthig EM (2000) Composition, biomass and potential grazing impact of the crustacean and pelagic tunicates in the northern Humboldt Current area off Chile: differences between El Niño and non-El Niño years. Mar Ecol Prog Ser 195: 201-220

Harbison GR, Gilmer RW (1976) The feeding rates of the pelagic tunicate Pegea confoederata and two other salps. Limnol and Oceanogr 21: 517-528

Harbison GR, McAlister (1979) The filter-feeding rates and particle retention efficiencies of three species of Cyclosalpa (Tunicata: Thaliacea). Limnol and Oceanogr 24: 875-892

Harbison GR, McAlister VL, Gilmer RW (1986) The response of the salp, Pegea confoederata, to high levels of particulate material: starvation in the midst of plenty. Limnol Oceanogr 31: 371-382

Henschke N, Bowden DA, Everett JD, Holmes SP, Kloser RJ, Lee RW, Suthers IM (2013) Salp-falls in the Tasman Sea: a major food input to deep-sea benthos. Mar Ecol Prog Ser 491: 165-175

Henschke N, Everett JD, Baird ME, Taylor MD, Suthers IM (2011) Distribution of life-history stages of the salp Thalia democratica in shelf waters during a spring bloom. Mar Ecol Prog Ser 430: 49-62

Henschke N, Everett JD, Doblin MA, Pitt KA, Richardson AJ, Suthers IM (2014) Demography and interannual variability of salp swarms (Thalia democratica). Mar Biol 161: 149-163

Hereu CM, Lavaniegos BE, Gaxiola-Castro G, Ohman MD (2006) Composition and potential grazing impact of salp assemblages off Baja California during the 1997-1999 El Niño and La Niña. Mar Ecol Prog Ser 318: 123-140

Hereu CM, Lavaniegos BE, Goericke R (2010) Grazing impact of salp (Tunicata, Thaliacea) assemblages in the eastern tropical North Pacific. J Plankton Res 32(6): 785-804

Huntley ME, Sykes PF, Marin V (1989) Biometry and trophodynamics of Salpa thompsoni Foxton (Tunicata: Thaliacea) near the Antarctic peninsula in Austral summer, 1983-1984. Polar Biol 10:59-70

Huskin I, Elices Ma.J, Anadón R (2003) Salp distribution and grazing in a saline intrusion off NW Spain. J Mar Syst 42: 1-11

Iseki K (1981) Particulate organic matter transport to the deep sea by salp fecal pellets. Mar Ecol Prog Ser 5: $55-60$ 

Lavaniegos BE, Ohman MD (2007) Coherence of long-term variations of zooplankton in two sectors of the California Current System. Prog Oceanogr 75: 42-69

590

591

592

593

594

595

596

597

598

599

600

601

602

603

604

605

606

607

608

609

610

611

612

613

614

615

616

617

618

619

620

Lebrato M, Mendes PJ, Steinberg DK, Cartes JE and others (2013a) Jelly biomass sinking speed reveals a fast carbon export mechanism. Limnol Oceanogr 58: 1113-1122

Lebrato M, Molinero J-C, Cartes J, Lloris D, Mélin F, Beni-Casadella L (2013b) Sinking jelly-carbon unveils potential environmental variability along a continental margin. PLoS ONE 8(12): e82070

Lebrato M, Pahlow M, Oschlies A, Pitt KA, Jones DOB, Molinero JC, Condon RH (2011) Depth attenuation of organic matter export associated with jelly falls. Limnol Oceanogr 56(5): 1917-1928

Lebrato M, Pitt KA, Sweetman AK, Jones DOB, Cartes JE, Oschlies A, Condon RH, Molinero JC, Adler L, Gaillard C, Lloris D, Billett DSM (2012) Jelly-falls historic and recent observations: a review to drive future research directions. Hydrobiol 690: 227-245

Li K, Yin J, Huang L, Shang J, Lian S, Liu C (2011) Distribution and abundance of thaliaceans in the northwest continental shelf of South China Sea, with response to environmental factors driven by monsoon. Cont Shelf Res 31: 979-989

Licandro P, Ibañez F, Etienne M (2006) Long-term fluctuations (1974-1999) of the salps Thalia democratica and Salpa fusiformis in the Northwestern Mediterranean Sea: relationships with hydroclimatic variability. Limnol Oceanogr 51: 1832-1848

Loeb VJ, Hofmann EE, Klinck JM, Osmund HH (2010) Hydrographic control of the marine ecosystem in the South Shetland-Elephant Island and Bransfield Strait region. Deep-Sea Res II 57: 519-542

Lomas MW, Bates NR, Johnson RJ, Knap AH, Steinberg DK, Carlson CA (2013) Two decades and counting: 24-years of sustained open ocean biogeochemical measurements in the Sargasso Sea. Deep-Sea Res II 93: 16-32

Lomas MW, Steinberg DK, Dickey T, Carlson CA, Nelson NB, Condon RH, Bates NR (2010) Increased ocean carbon export in the Sargasso Sea linked to climate variability is countered by its enhanced mesopelagic attenuation. Biogeosciences 7: 57-70

Madin LP (1974) Field observations on the feeding behavior of salps (Tunicata: Thaliacea). Mar Biol 25: $143-147$

Madin LP (1982) Production, composition and sedimentation of salp pellets in oceanic waters. Mar Biol 67: $39-45$

Madin LP, Cetta CM (1984) The use of gut fluorescence to estimate grazing by oceanic salps. J Plankton Res 6(3): 475-492

Madin LP, Deibel D (1998) Feeding and energetics of Thaliacea. In: Bone Q (ed) The biology of pelagic tunicates. Oxford University Press, Oxford, p 81-103 
621 Madin LP, Kremer P, Hacker S (1996) Distribution and vertical migration of salps (Tunicata, Thaliacea)

622 near Bermuda. J Plankton Res 18: 747-755

623 Madin LP, Kremer P, Wiebe PH, Purcell JE, Horgan EH, Nemazie DA (2006) Periodic swarms of the

624 salp Salpa aspera in the Slope Water off the NE United States: Biovolume, vertical migration, grazing,

625 and vertical flux. Deep-Sea Res I 53: 804-819

626 Madin LP, Horgan EF, Steinberg DK (2001) Zooplankton at the Bermuda Atlantic Time-series Study

627 (BATS) station: diel, seasonal and interannual variation in biomass, 1994-1998. Deep-Sea Res II 48:

$628 \quad 2063-2082$

629 Madin LP, Purcell JE (1992) Feeding, metabolism, and growth of Cyclosalpa bakeri in the subarctic

630 Pacific. Limnol and Oceanogr 37: 1236-1251

631 Matsueda H, Handa N, Inoue I, Takano H (1986) Ecological significance of salp fecal pellets collected by

632 sediment traps in the eastern North Pacific. Mar Biol 91: 421-431

633 Ménard F, Dallot S, Thomas G, Braconnot JC (1994) Temporal fluctuations of two Mediterranean salp 634 populations from 1967 to 1990. Analysis of the influence of environmental variables using a Markov 635 chain model. Mar Ecol Prog Ser 104: 139-152

636 Moseley HN (1880) Deep-sea dredging and life in the deep sea III. Nature 21: 591-593

637 Mullin MM (1983) In situ measurement of filtering rates of the salp, Thalia democratica, on

638 phytoplankton and bacteria. J Plankton Res 5: 279-288

639 Phillips B, Kremer P, Madin LP (2009) Defecation by Salpa thompsoni and its contribution to vertical 640 flux in the Southern Ocean. Mar Biol 156: 455-467

641 Purcell JE, Graham WM, Dumont H (eds) (2001) Jellyfish blooms: ecosystem and societal importance. 642 Developments in hydrobiology 155. Kluwer Academic Publishers, Dordrecht

643 Reinke M (1987) On the feeding and locomotory physiology of Salpa thompsoni and Salpa fusiformis. 644 Rep Polar Res 36: 89

645 Ristow GH (1997) Wall correction factor for sinking cylinders in fluids. Phys Rev E 55(3): 2808-2813

646 Roman MR, Adolf HA, Landry MR, Madin LP, Steinberg DK, Zhang X (2002) Estimates of oceanic

647 mesozooplankton production: a comparison using the Bermuda and Hawaii time-series data. Deep-Sea 648 Res II 49: 175-192

649 Roman MR, Dam HG, Gauzens AL, Napp JM (1993) Zooplankton biomass and grazing at the JGOFS 650 Sargasso Sea time series station. Deep-Sea Res I 40(5): 883-901

651 Saba VS, Friedrichs MAM, Carr M-E, Antoine D and others (2010) Challenges of modeling depth652 integrated marine primary productivity over multiple decades: a case study at BATS and HOT. Global 653 Biogeochem Cycles 24: GB3020, doi:10.1029/2009GB003655 
654

655

656

657

658

659

660

661

662

663

664

665

666

667

668

669

670

671

672

673

674

675

676

677

678

679

680

681

682

683

684

685

686

687

Sempéré R, Yoro SC, Wambeke FV, Charrière B (2000) Microbial decomposition of large organic particles in the northwestern Mediterranean Sea: an experimental approach. Mar Ecol Prog Ser 198: 6172

Shatova O, Koweek D, Conte MH, Weber JC (2012) Contribution of zooplankton fecal pellets to deep ocean particle flux in the Sargasso Sea assessed using quantitative image analysis. J Plankton Res 34(10): 905-921

Small LF, Fowler SW, Moore SA, La Rosa J (1983) Dissolved and fecal pellet carbon and nitrogen release by zooplankton in tropical waters. Deep-Sea Res 30: 1199-1220

Smith Jr. KL, Sherman AD, Huffard CL, McGill PR, Henthorn R, Von Thun S, Ruhl HA, Kahru M, Ohman MD (2014) Large salp bloom export from the upper ocean and benthic community response in the abyssal northeast Pacific: Day to week resolution. Limnol Oceanogr 59(3): 745-757

Sreekumaran Nair SR, Achuthankutty CT, Bhattathiri PMA, Madhupratap M (1995) Feeding behaviour of salp Thalia democratica (Thaliacea). Indian Journal of Marine Sciences 24: 102-103

Steinberg DK, Carlson CA, Bates NR, Goldthwait SA, Madin LP, Michaels AF (2000) Zooplankton vertical migration and the active transport of dissolved organic and inorganic carbon in the Sargasso Sea. Deep-Sea Res I 47: 137-158

Steinberg DK, Carlson CA, Bates NR, Johnson RJ, Michaels AF, Knap AH (2001) Overview of the US JGOFS Bermuda Atlantic Time-series Study (BATS): a decade-scale look at ocean biology and biogeochemistry. Deep-Sea Res II 48: 1405-1447

Steinberg DK, Lomas MW, Cope JS (2012) Long-term increase in mesozooplankton biomass in the Sargasso Sea: linkage to climate and implications for food web dynamics and biogeochemical cycling. Global Biogeochem Cycles 26: GB1004, doi:10.1029/2010GB004026

Stone JP, Steinberg DK (2014) Long-term time-series study of salp population dynamics in the Sargasso Sea. Mar Ecol Prog Ser 510: 111-127

Sutherland KR, Madin LP, Stocker R (2010) Filtration of submicrometer particles by pelagic tunicates. Proc Natl Acad Sci USA 107: 15129-15134

Vargas CA, Madin LP (2004) Zooplankton feeding ecology: clearance and ingestion rates of the salps Thalia democratica, Cyclosalpa affinis and Salpa cylindrica on naturally occurring particles in the MidAtlantic Bight. J Plankton Res 26(7) 827-833

Wallhead PJ, Garçon, Casey JR, Lomas MW (2014) Long-term variability of phytoplankton carbon biomass in the Sargasso Sea. Global Biogeochem Cycles 28, doi:10.1002/2013GB004797

Wiebe PH, Madin LP, Haury LR, Harbison GR, Philbin LM (1979) Diel vertical migration by Salpa aspera and its potential for large-scale particulate organic matter transport to the deep-sea. Mar Biol 53: 249-255 
688 Wu S, Liu Z, Zhang R, Delworth TL (2011) On the observed relationship between the Pacific Decadal 689 Oscillation and the Atlantic Multi-decadal Oscillation. J Oceanogr 67: 27-35

690 Yoon WD, Kim SK, Han KN (2001) Morphology and sinking velocities of fecal pellets of copepod, 691 molluscan, euphausiid, and salp taxa in the northeastern tropical Atlantic. Mar Biol 139: 923-928

692 
Figure and table captions

700

701

702

703

704

705

706

707

708

709

710

711

712

713

714

715

716

717

718

719

720

Table 1: Warm-water decomposition rates for three species of salps and for all measured species combined. The equation solves for the percent $(\mathrm{P})$ of the starting salp dry weight remaining after $\mathrm{H}$ hours. Decomposition follows an exponential decay curve, with a faster decay rate followed by slower decomposition.

Table 2: Average annual carbon flux from the 9 largest contributors to flux and all other species combined. Shown are fluxes of fecal pellets, sinking of dead carcasses, respiration at depth of dielvertical migrators, and the total of those three categories. Values are in $\mathrm{mg}$ carbon $\mathrm{m}^{-2}$ year ${ }^{-1}$, and \pm standard deviation. DOC excretion is less than $0.1 \mathrm{mgC} \mathrm{m}^{-2}$ year ${ }^{-1}$ for all species combined.

Figure 1: A summary of the model. Black boxes indicate forced values from BATS data (phytoplankton biomass, salp biomass, and salp diel vertical migration), red boxes indicate modeled rates (grazing, fecal pellet production (FPP), sinking carcasses, respiration, dissolved organic carbon (DOC) excretion, and decomposition) and outputs (shallow and deep salp carbon), and blue arrows indicate carbon flow.

Figure 2: Mean carcass sinking rate for eight species of salps, arranged from largest salp on the left to smallest on the right. Blue circles are the wall-interaction corrected values of the measured sinking rates (black circles). Error bars are standard error, and $\mathrm{n}$ for each species is in parentheses after name.

Figure 3: Percent of starting salp dry weight remaining after decomposing in surface waters. Data from 7 species and 96 individuals were used to fit the exponential decay regression. Experiments were carried out in March, May, and August of 2014 using surface water that ranged from $19-23^{\circ} \mathrm{C}$.

Figure 4: A) Daily chlorophyll a concentration (blue) and calculated amount of chlorophyll a grazed by total salps each day (black). B) Annual primary production (integrated to 140m) from 1995 to 2010 (black bars) and calculated percent of that annual PP c grazed by total salps for each year (gray bars). 
721 Figure 5: A) Total salp daily carbon flux to $200 \mathrm{~m}$ (green) and $3200 \mathrm{~m}$ (blue) at BATS. Total flux is from 722 all salp species and is combined fecal pellet export, sinking of salp carcasses, and respiration and DOC 723 excretion by DVM at depth. Blue lines without corresponding green indicate $3200 \mathrm{~m}$ flux that is nearly 724 equal to the $200 \mathrm{~m}$ flux. B) Percent calculated total salp flux of daily primary production (integrated to $725140 \mathrm{~m})$.

726 Figure 6: Seasonal variation in the salp flux to 200m of carcasses (red), fecal pellets (black), respiration 727 below 200m (blue), and DOC excretion below 200m (green). Average (A) and median (B) daily salp 728 carbon flux for each Julian day are shown from the entire time series.

729 Figure 7: The percent of the total salp carbon flux at 200m for each of the top 5 species at the BATS site 730 for (A) the sum of each species' contribution across the entire time series and (B) the average annual 731 percent contribution for years 1995-2010.

732 Figure 8: (A) Annual totals from 1995-2010 for combined salp carbon flux to 200m, and the proportion 733 different sources (fecal pellets, respiration, sinking of dead carcasses, and dissolved organic carbon 734 excretion) contribute to those totals. These totals are compared to (B) the total annual BATS sediment 735 trap flux at 200m by calculating (C) the percent salp flux of the total BATS trap flux at 200m.

Figure 9: Depth attenuation of modeled salp carbon flux (black bars) and measured sediment trap flux

737 (red bars). Modeled data are averaged from January 1994 to December 2011; 200 and 300m sediment 738 trap fluxes are from the BATS dataset and averaged from January 1989 to December 2011; and 500, 739 1500, and 3200m sediment trap fluxes are collected from Conte et al. (2001). 


\begin{tabular}{|l|l|l|l|}
\hline Species & Equation & $\mathbf{R}^{2}$ & $\mathbf{p}$ \\
\hline Iasis zonaria & $\mathbf{P}=\mathbf{1 0 8}^{*} \mathrm{e}^{\wedge}(-\mathbf{0 . 0 3 3} * \mathbf{H})$ & $\mathbf{0 . 6 7}$ & $<\mathbf{0 . 0 0 1}$ \\
\hline Salpa fusiformis & $\mathbf{P}=101 * \mathbf{e}^{\wedge}(-\mathbf{0 . 1 6 4} * \mathbf{H})$ & $\mathbf{0 . 8 7}$ & $<\mathbf{0 . 0 0 1}$ \\
\hline Thalia democratica & $\mathbf{P}=95 * \mathbf{9}^{\wedge}(-\mathbf{0 . 6 0 5} * \mathbf{H})$ & $\mathbf{0 . 8 4}$ & $<\mathbf{0 . 0 0 1}$ \\
\hline $\begin{array}{l}\text { All species } \\
\text { combined }\end{array}$ & $\mathbf{P}=\mathbf{1 0 4}^{*} \mathbf{e}^{\wedge}(-\mathbf{0 . 0 9 0} * \mathbf{H})$ & $\mathbf{0 . 6 4}$ & $<\mathbf{0 . 0 0 1}$ \\
\hline
\end{tabular}

Table 1

\begin{tabular}{|c|c|c|c|c|}
\hline Species & $\begin{array}{c}\text { Fecal Pellets } \\
\text { mgC m}^{-2} \text { year }^{-1}\end{array}$ & 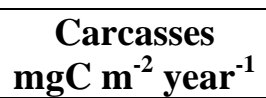 & 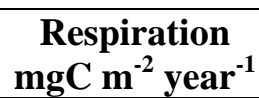 & 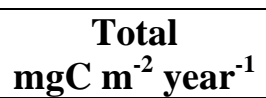 \\
\hline Thalia democratica & $417 \pm 1160$ & $0.4 \pm 1.1$ & $\mathbf{0}$ & $418 \pm 1160$ \\
\hline Salpa aspera & $60.9 \pm 117$ & $7.6 \pm 14.0$ & $58.4 \pm 112$ & $127 \pm 243$ \\
\hline Salpa fusiformis & $47.9 \pm 42.9$ & $6.5 \pm 5.8$ & $46.0 \pm 41.2$ & $100 \pm 90$ \\
\hline Iasis zonaria & $18.3 \pm 24.7$ & $3.9 \pm 5.5$ & $14.5 \pm 19.6$ & $37 \pm 50$ \\
\hline Wheelia cylindrica & $10.4 \pm 26.7$ & $1.3 \pm 2.8$ & $18.9 \pm 48.6$ & $31 \pm 78$ \\
\hline Salpa maxima & $13.0 \pm 50.1$ & $1.1 \pm 4.3$ & $\mathbf{0}$ & $14 \pm 54$ \\
\hline $\begin{array}{l}\text { Pegea } \\
\text { confoederata }\end{array}$ & $6.7 \pm 17.6$ & $0.4 \pm 1.2$ & $\mathbf{0}$ & $7.1 \pm 19$ \\
\hline Pegea socia & $4.9 \pm 16.1$ & $0.9 \pm 3.1$ & $\mathbf{0}$ & $5.9 \pm 19.2$ \\
\hline Ritteriella retracta & $1.9 \pm 3.6$ & $0.2 \pm 0.6$ & $1.3 \pm 3.1$ & $3.5 \pm 8.1$ \\
\hline Other & $4.8 \pm 5.1$ & $0.6 \pm 0.5$ & $\mathbf{0}$ & $5.3 \pm 5.5$ \\
\hline Total & $586 \pm 1140$ & $23.0 \pm 19.5$ & $139 \pm 126$ & $749 \pm 1130$ \\
\hline
\end{tabular}

Table 2 


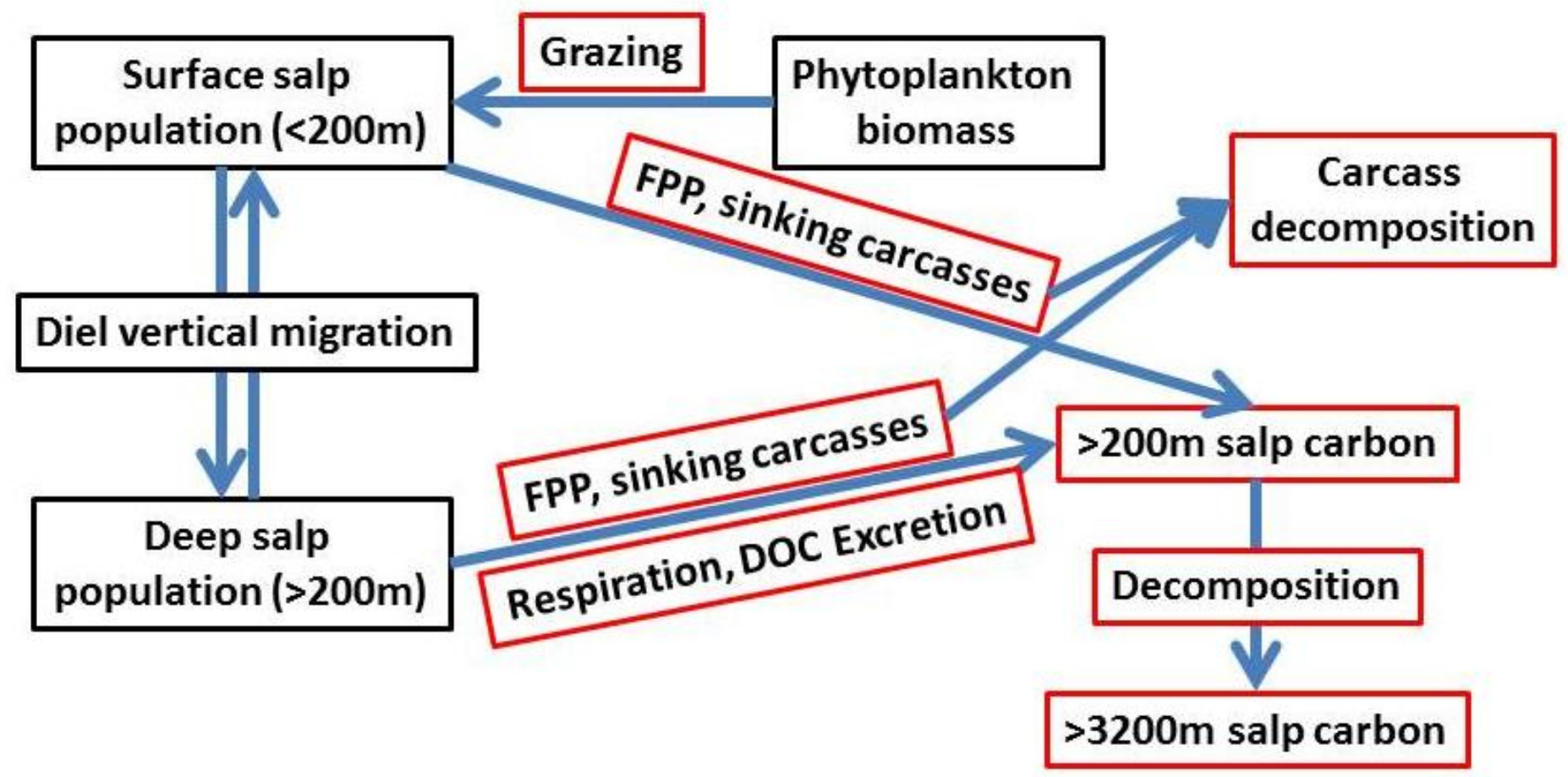

Figure 1 


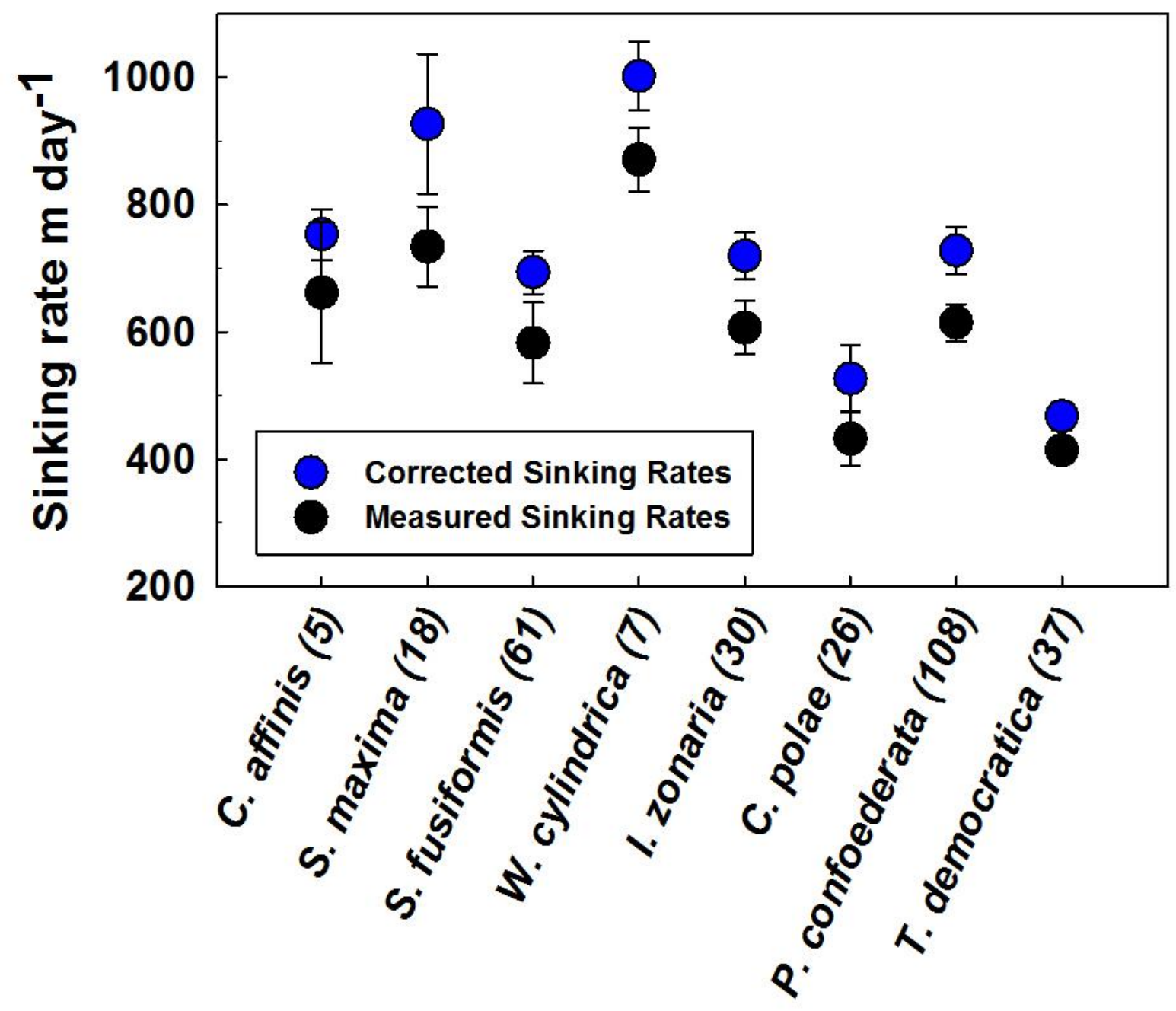

Figure 2 
All salps warm water

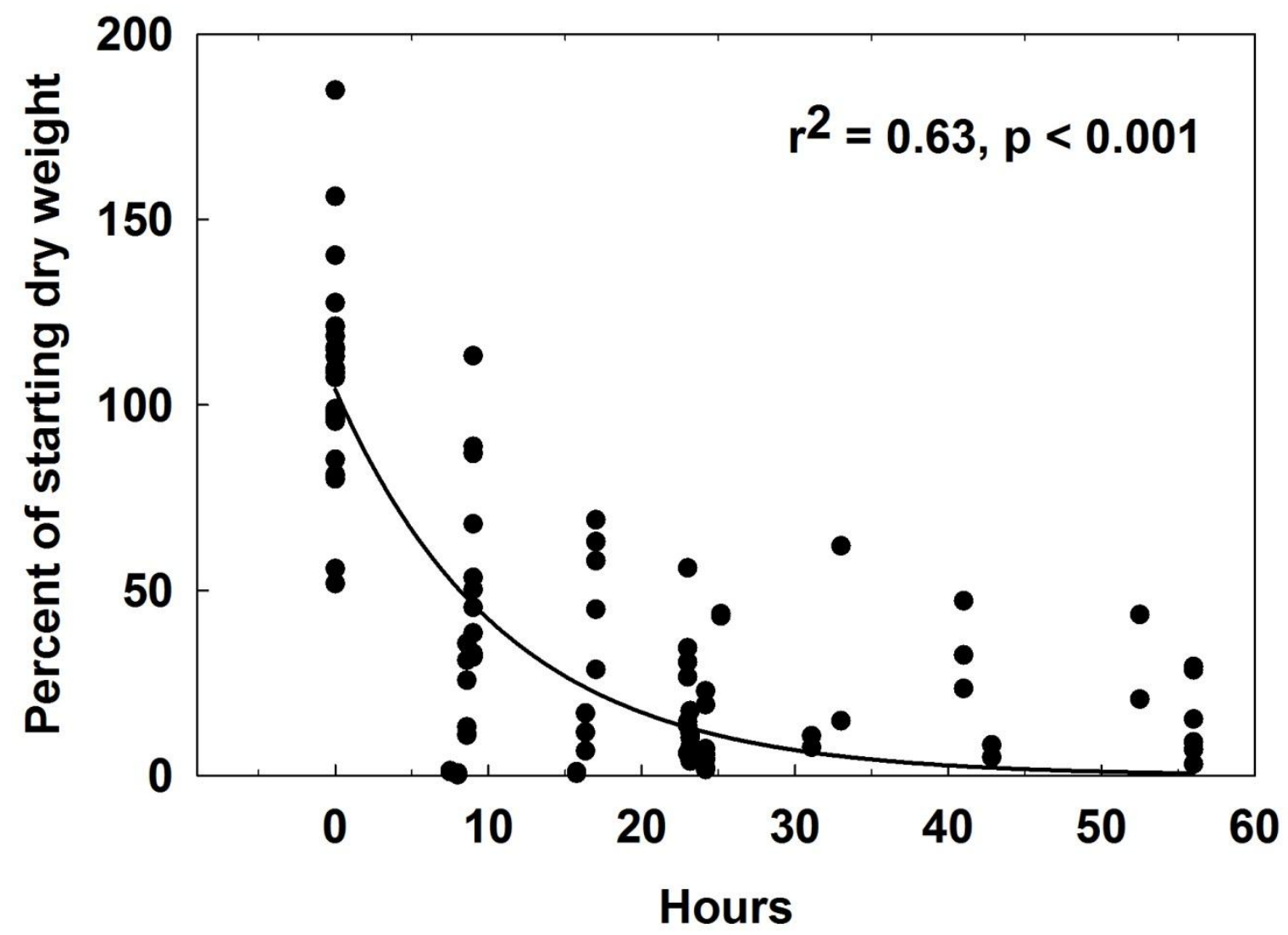

Figure 3 
Date

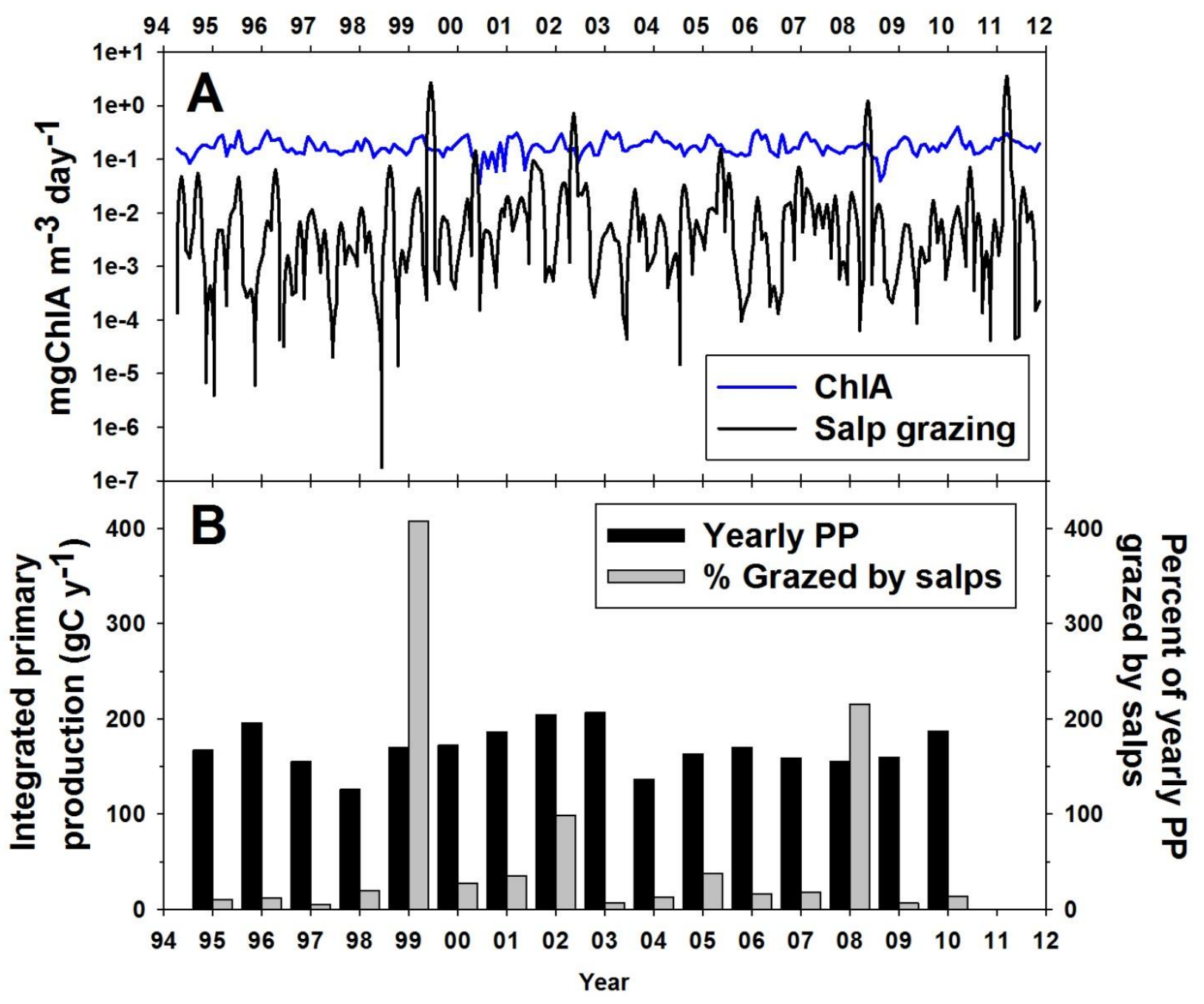

Figure 4 


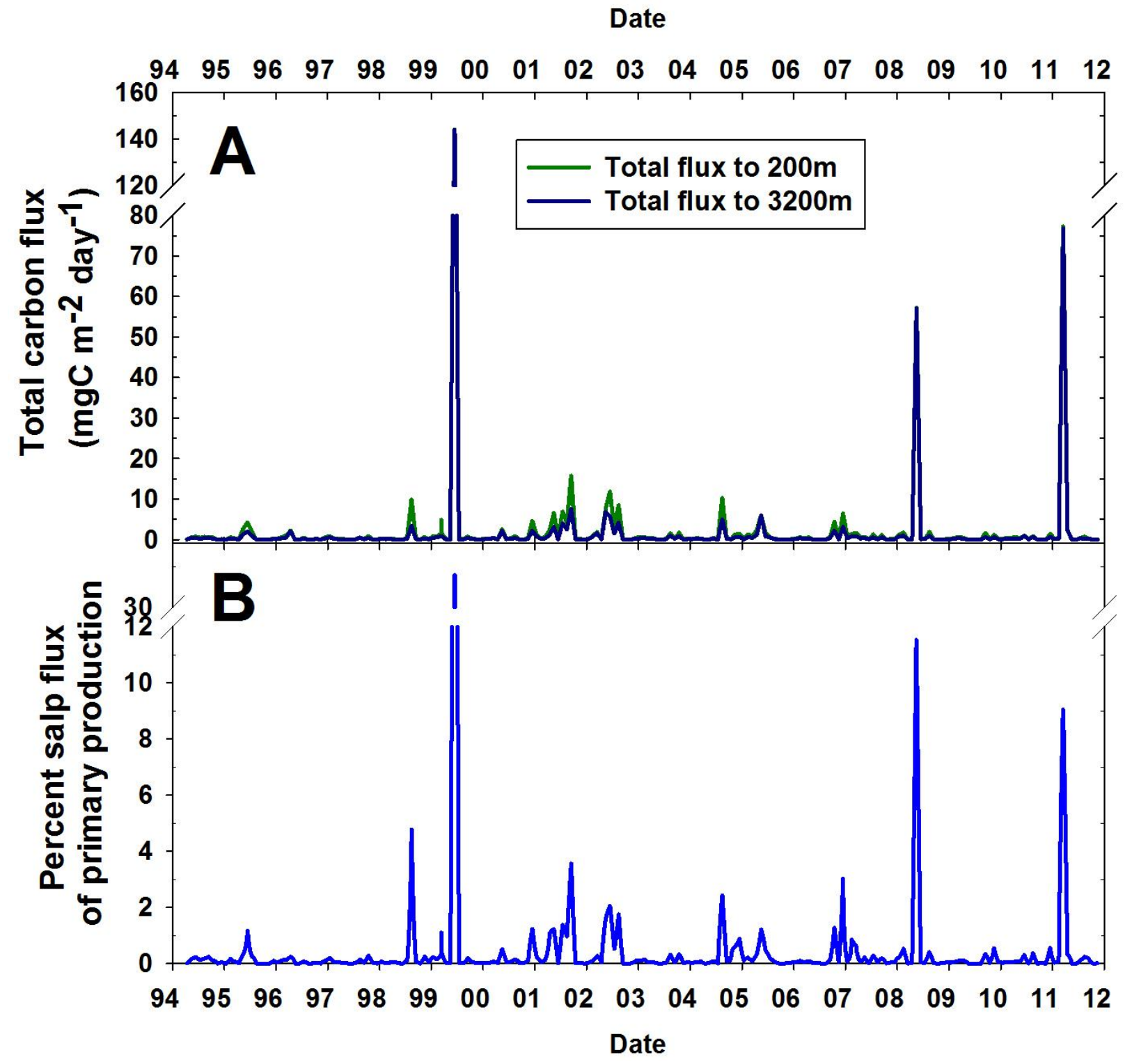

Figure 5 
Date

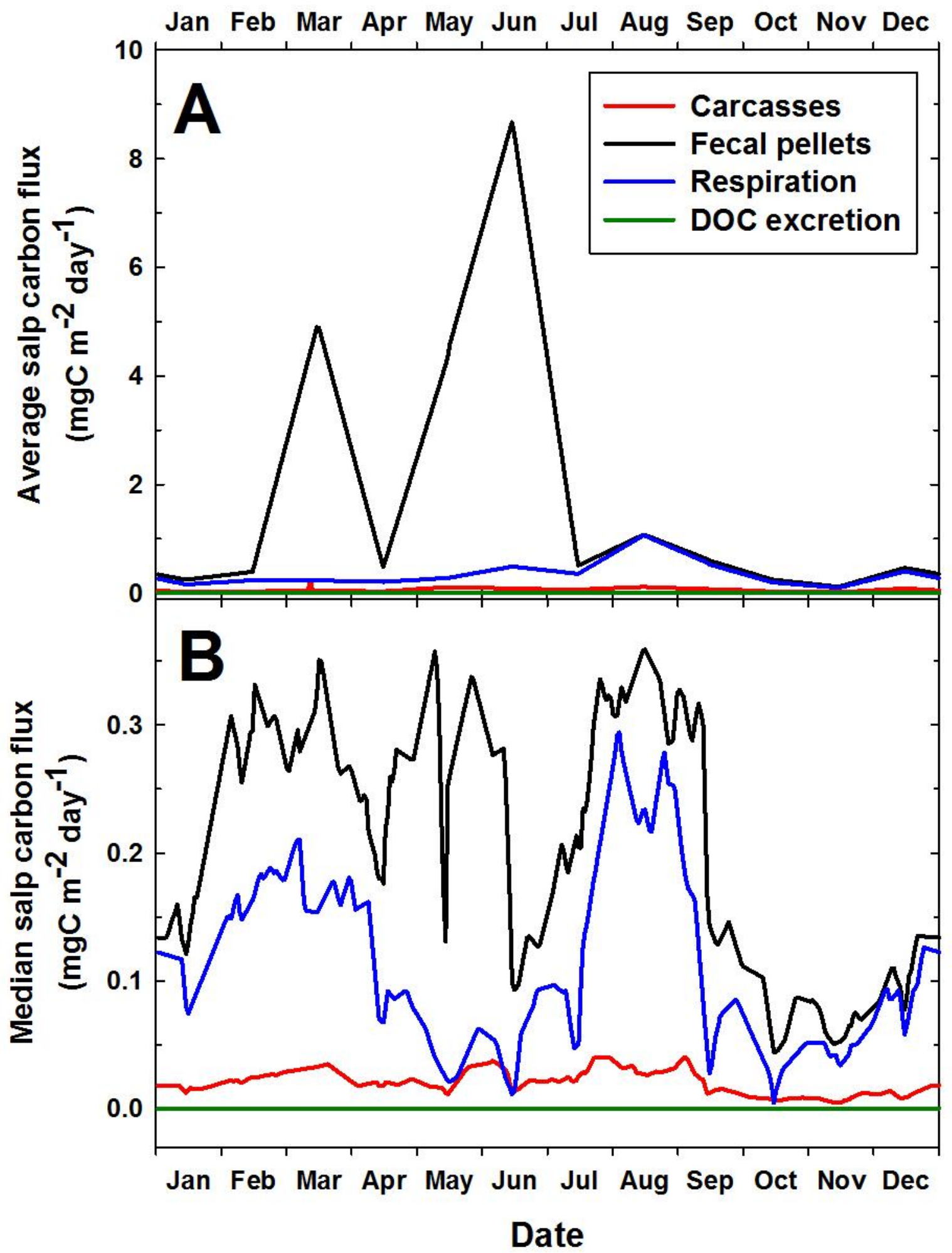

Figure 6 


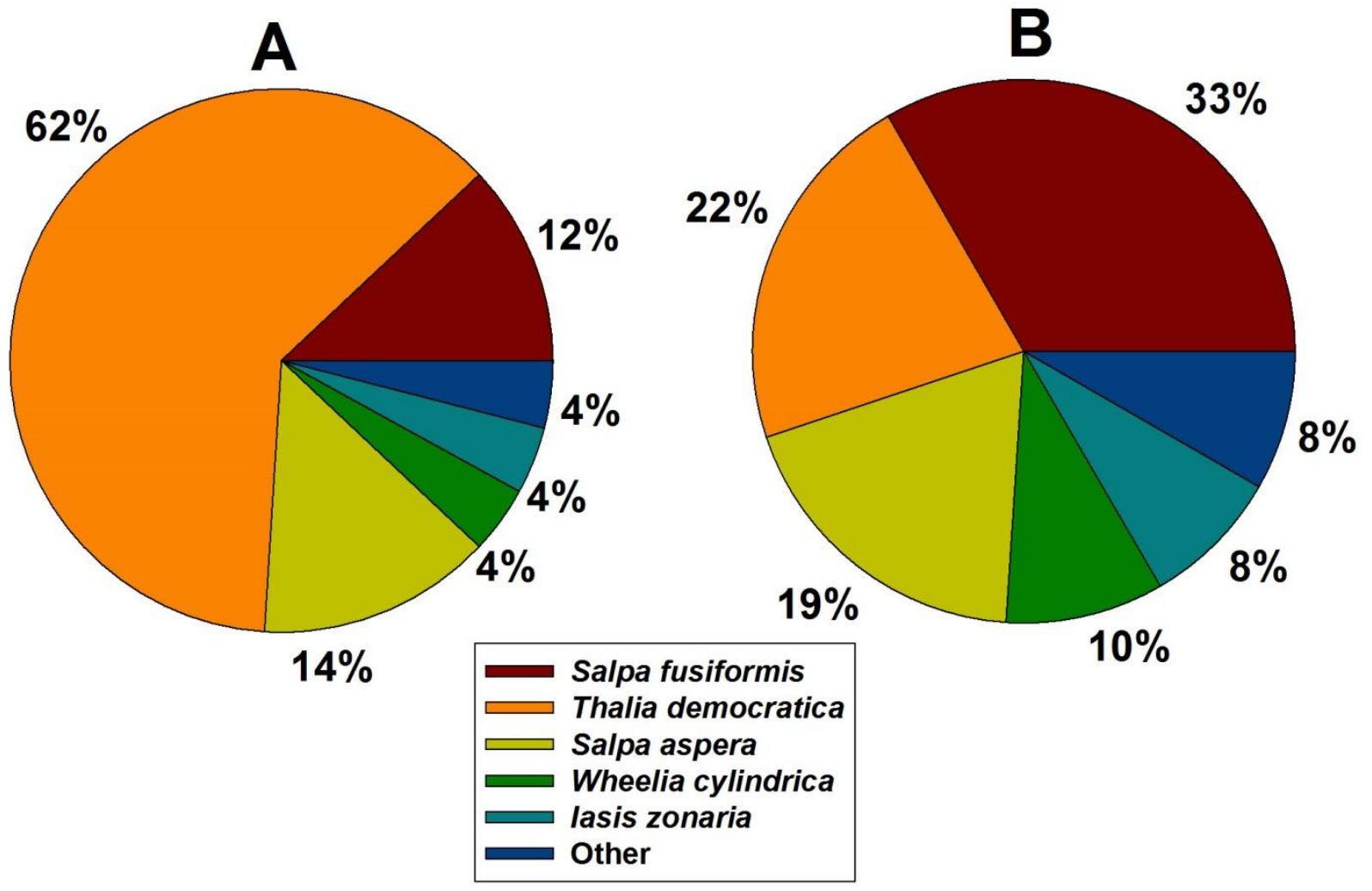

Figure 7 


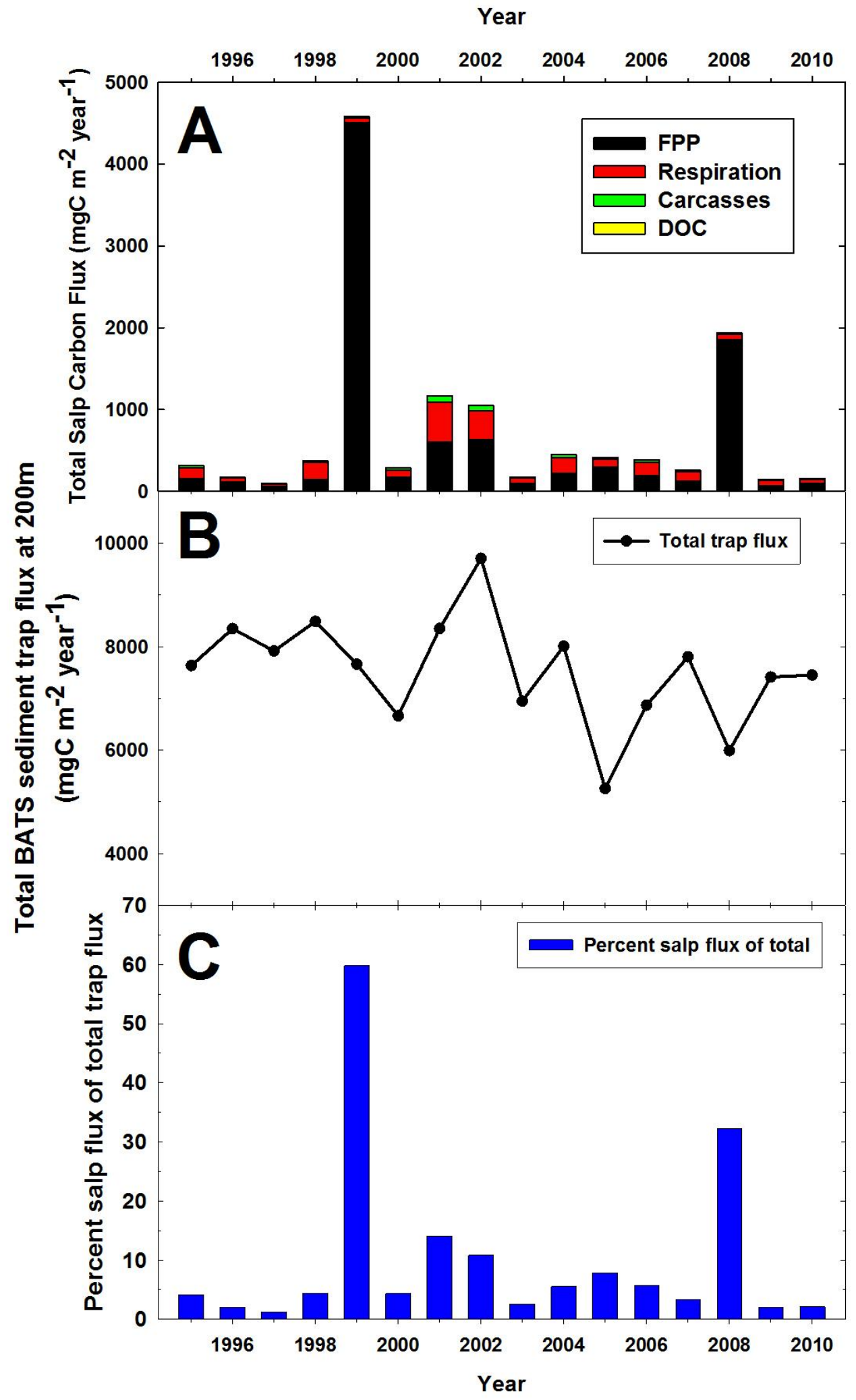

Figure 8 


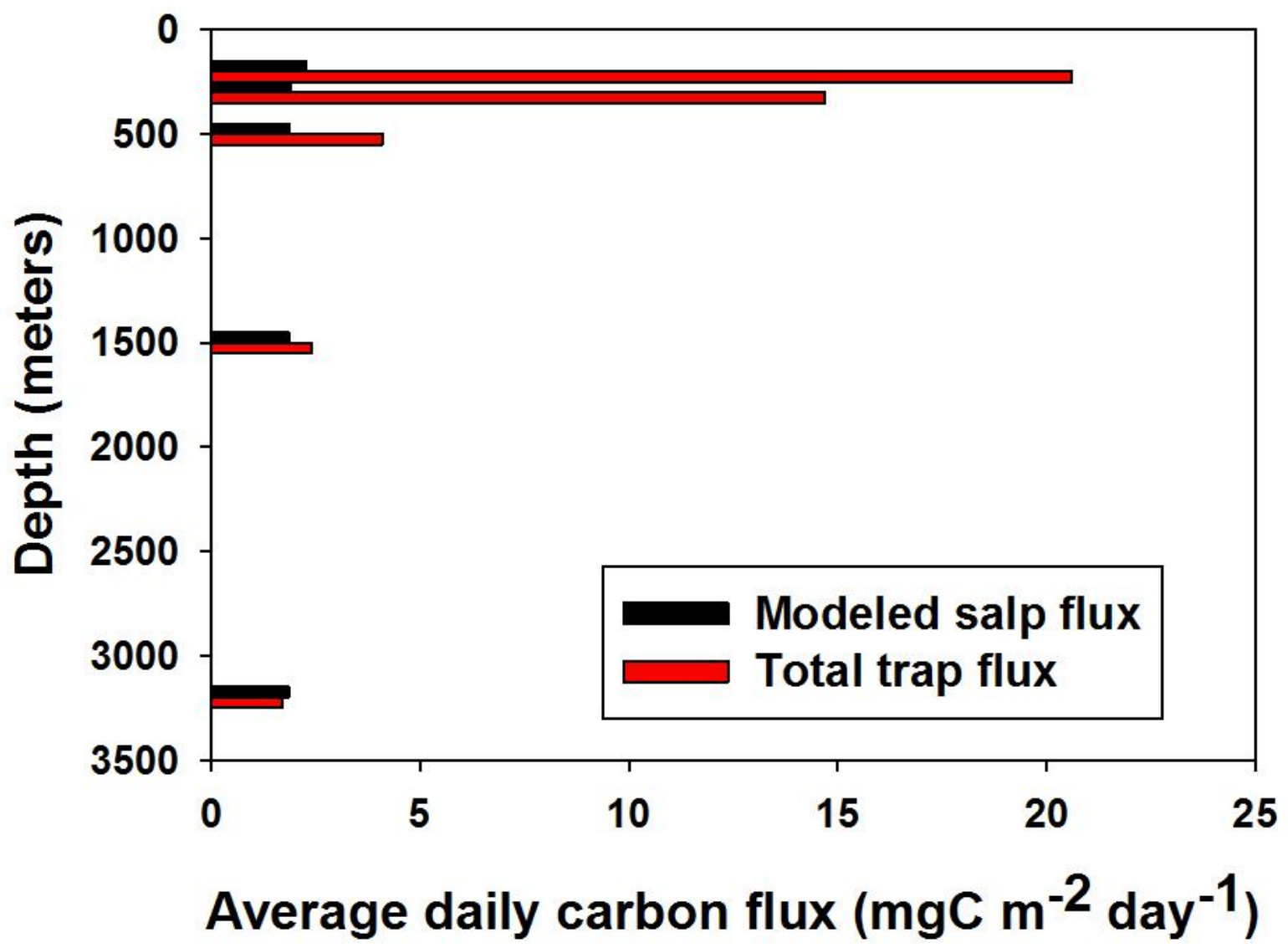

Figure 9 